\title{
A Research study on Job Satisfaction and Attitudes Towards Ethic Codes: Is There a Relationship between Job Satisfaction and Attitudes Towards Ethic Codes?
}

\author{
Murat Delice * \\ * Kilis Emniyet Müdürlüğü \\ E-mail: muratdelicekos@yahoo.com
}

Copyright (C) 2016 Murat Delice. This is an open access article distributed under the Eurasian Academy of Sciences License, which permits unrestricted use, distribution, and reproduction in any medium, provided the original work is properly cited.

\begin{abstract}
Job satisfaction and codes of ethic are vital phenomenons affecting organizations' success. Because the services presented by The Turkish National Police are related to citizens' security, rights and life quality, police officers' level of job satisfaction and attitudes towards codes of ethic have a critic role in the organization. Therefore, this current study investigated police officers' level of job satisfaction and attitudes towards codes of ethic. Since it was hypothesized that one of the consequences of low level of job satisfaction might be negatives attitudes towards police codes of ethic, this study also investigated the relationship between these two phenomenons. Data were collected from 314 police officers through questionnaires. Data were analyzed using descriptive statistics, t-test, ANOVA and Pearson Product Moment Correlation on SPSS 17.0. Findings showed that police officers had a mid-level job satisfaction. They perceived that some of unethical behaviors are more serious than some others, and they thought these more serious unethical behaviors should be punished more severely. On the other hand, they believed these more serious unethical behaviors are seen less frequently in the organization. More importantly, findings showed that there are partly significant relationships between seriousness levels of unethical behaviors and level of job satisfaction. These findings might be useful to better understand police officers' job satisfaction and their attitudes towards codes of ethic. Findings can guide the police organization to increase police officers' job satisfaction and to educate officers in terms of code of conducts.
\end{abstract}

Keywords: Job Satisfaction, Code of Conduct, Ethic, Police, Corruption

\section{İş Doyumu Ve Meslek Etiği Tutumu Üzerine Bir Araştırma: İş Doyumu İle Etik Tutum Arasında Bir İlişki Var mı?}

\section{ÖZET}

İş doyumu ve meslek etiği olguları, örgütlerin başarılarıyla yakından ilişkili iki önemli kavramdır. Türk Polis Teşkilatında yürütülen hizmetler halkın güvenliği, bireysel haklar ve hayat standardıyla yakından ilişkili olduğundan bu örgütte çalışanların iş doyum düzeyi ve onların meslek etiği kurallarına karşı geliştirdikleri tutumlar kritik bir öneme sahiptir. $\mathrm{Bu}$ araştırmada polislerin iş doyum düzeyi ve iş etiği tutumları incelenmiştir. İş doyum düzeyinin örgütler için pek çok olumsuz yansımalarından birisinin de çalışanların meslek etiği ilkelerine karşı olumsuz bir tutum geliştirmesi olabileceği varsayılarak bu iki olgu arasındaki ilişkiler araştırılmıştır. Veriler 314 polis memurundan anket yöntemiyle toplanmıştır. Analizler SPSS 17.0 programı üzerinde betimsel istatistikler, t-test, ANOVA ve korelâsyon testleri kullanılarak 
yapılmıştır. Bulgular, polislerin iş doyumunun orta düzeyde olduğunu, polislerin bazı etik dışı davranışları diğer bazılarına göre daha ciddi ve önemli gördüklerini, daha ciddi görülen etik dışı davranışlara daha yüksek düzeyde ceza öngördüklerini, ancak daha ciddi görülen etik dış1 davranışların polis teşkilatında daha nadir yaşandığını düşündüklerini göstermiştir. Daha önemlisi, bu araştırmada polislerin etik dışı davranışları ciddi ve önemli görme düzeylerinin onların iş doyum düzeyiyle kısmen de olsa ilişkili olduğu bulunmuştur. Polislerin iş doyum davranışını ve meslek etiği tutumlarını anlamak ve bu iki olgu açısından polis teşkilatında doğru adımlar atabilmek bu bulguların yararlı olabileceği değerlendirilmektedir.

Anahtar Kelimeler: İş Doyumu, Meslek Etiği, Polis, Yozlaşma

\section{GiRiş}

İş doyumu ve meslek etiği örgütler için iki önemli olgudur. İş doyumu; işgörenin işine karş1 hissettikleri, işgörenin iş yerini sevme düzeyi ve işgörenin işinin farklı yönlerine karşı geliştirdiği tutumların bütünü olarak tanımlanabilir (Burney ve Swanson, 2010; Davis, 2004: 496; Sun, 2002: 3). İş doyum düzeyinin yüksekliği; örgütsel bağlılığı artırmak, işgören ilişkilerini geliştirmek, örgüt içi iletişimi yükseltmek, performans artışı sağlamak, yönetim ve karar verme süreçlerini kolaylaştırmak gibi örgütler açısından hayati faydalar sağlamaktadır (Köroğlu, 2011; Sığrı ve Basım, 2006; Yüksel, 2003). Tersine, iş doyum düzeyinin düşüklüğü ise işgörenin sağlığının kırılgan olması, stres, sigara ve alkol gibi bağımlılıklar, işten ayrılma, devamsızlık, işi geciktirmek, moralsizlik, verim ve performans düşüklüğü gibi ciddi olumsuzluklara neden olabilmektedir (Akınc1, 2002; Erdem ve Demirel, 2009; Malhotra ve Mukherjee, 2004; Sevimli ve İşçan, 2005; Solmuş, 2004; Spector, 1997).

Örgütler için iş doyumu kadar önemli bir diğer olgu meslek etiğidir. Etik; davranışlar arasında seçim yapmamıza ve neyi yapacağımız konusunda bir değerlendirme yapmamıza yardım eden kurallar ve değerler bütünü olarak (Davis, 1991) tanımlandığı gibi meslek etiğgi de bir mesleğin icrasıyla ilgili olarak çalışanların davranışlarını belirleyen ve yönlendiren ahlaki, vicdani ve hukuki kuralların ve prensiplerin bütünü (MEB, 2006) olarak tanımlanabilir. Meslek etiği ilkeleri işgörenin davranışlarını kontrol etmesini, meslek içi rekabetin düzenlenmesini, insani eğilimlerin sınırlanmasını, mesleğin gereğinin yüksek düzeyde icra edilmesini ve mesleki kurallara uymayanların meslekten uzaklaştırmasını sağladığından (Beren, 2001; Deliorman ve Kandemir, 2009) örgütler için önemli bir olgu olarak kabul edilir. Bir örgütte meslek etiği kurallarına uyulmuyor olması o örgütün çalışanlarının yozlaştığı anlamına gelir. Yozlaşma ise örgütün imajını ve şöhretini olumsuz etkiler, motivasyonu düşürür, verimi ve performansı düşürür ve bu etkileriyle yozlaşma örgütün devamını ve varlığını tehdit eder (Atmaca, 2010; Boles, 1995; DeShon, 2000; IACP, 2012; Wyatt-Nichol ve Franks, 2009).

Her örgüt gibi Türk Polis Teşkilatı da çalışanlarının iş doyum düzeylerinin yüksek olmasına ve çalışanların meslek etiği ilkelerine en yüksek düzeyde oyuyor olmalarına ihtiyaç duyar. Hatta Türk Polis Teşkilatının bazı özellikleri bu teşkilatı iş doyumu ve meslek etiği olguları açısından daha hassas olmaya zorlayabilir. Polislik mesleğinde iş doyum düzeyini azaltma potansiyeli olan pek çok etken vardır. Bunlara örnek olarak; 24 saat çalışma sistemi, mesai saati belirsizlikleri, aşırı iş yükü, yapılan işin kritik ve çoğu zaman acil olması, yapılan işin tehlikeli ve riskli olması, katı hiyerarşik yapı ve bu yapıyla ilişkili olarak yönetim baskısı, yapılan işe karşın alınan ücretin yetersiz olması, emeklilik imkânlarının yetersiz olması, yapılan işlerin ve sorumlulukların açık ve net olmaması, üniformalı görev yapmak nedeniyle sürekli göz önünde olunması verilebilir (Aydın, 2003; Çam ve Çakır, 2008; Gül ve Delice; Gündüz, 
Erkan ve Gökçakan, 2007; Sever ve Cinoğlu, 2010; Yılmaz, 2011). Ayrıca polisler, topluma güvenlik hizmeti sunarlar ve kamu düzenini sağlarlar. İş doyum düzeyi nedeniyle oluşabilecek performans ve verim düşüklüğü halkın güvenlik ve huzurunu tehdit ediyor olacaktır. $\mathrm{Bu}$ nedenlerle Türk Polis Teşkilatı, çalışanlarının iş doyum düzeyini yüksek tutmak, bu konuya önem vermek ve onların iş doyum düzeylerini sıklıkla ölçmek konularında duyarlı olmalıdır.

Meslek etiği ilkeleri de Türk Polis Teşkilatı için son derece önemli bir olgudur. Çünkü polislik, vatandaş üzerinde durdurma, arama yapma, yakalama, iletişimi dinleme, silah kullanma ve zor kullanma gibi yetkileri olan nadir meslek gruplarındandır (Sözen, 2004). Polislerin meslek etiği ilkelerine uymuyor olması halkın güvenliğini tehlikeye soktuğu kadar bireylerin hak ve özgürlüklerini de tehdit etmektedir. Ayrıca, polise görevin ifası için verilmiş olan bu yetkiler yozlaşma konusunda başka meslek gruplarında olmadığı kadar imkânlar sunmaktadır (Cerrah, Çevik, Göksu ve Balcıoğlu, 2009; Masiapata, 2007). Polis Teşkilatında, yetkilerin kanunun belirlediği sınırlarda kullanılmasını sağlayacak ve yüksek bir performansla halkta memnuniyet yaratacak hizmetler sunulmasını sağlayacak önemli etkenlerden bir tanesi polislerin meslek etiği ilkelerine uyuyor olmalarıdır. Bu nedenlerle Türk Polis Teşkilatı, çalışanlarının meslek etiği kurallarına uymasını sağlamak, bu konuya önem vermek ve onların meslek etiği tutum ve algılarını sıklıkla ölçmek konularında da duyarlı olmalıdır.

Hem iş doyumu hem de meslek etiği kavramları literatürde sıklıkla incelenmiştir. Ancak bu iki kavram hiç ilişkilendirilmemiştir. Yukarıda iş doyumu düşük çalışanların işlerine karşı işten ayrılma, devamsızlık, işi geciktirmek gibi olumsuz tutumlar geliştirdikleri belirtilmişti. Benzer şekilde; iş doyum düzeyi düşüklüğünün çalışanların meslek etiği tutumlarında bir farklılaşma yaratabileceği değerlendirildiğinden iş doyum düzeyi ile meslek etiği tutumu arasındaki ilişki incelemeye değer görülmüştür. Bu araştırmanın hipotez olarak iş doyum düzeyi düşük olan çalışanların meslek etiği ihlallerine karşın geliştirdikleri tutumlar da daha düşük şiddette olacaktır ifadesi belirlenmiştir.

$\mathrm{Bu}$ araştırmada polislerin meslek etiği tutumlarının ve iş doyumlarının ölçülmesi, polislerin meslek etiği tutumlarını ve iş doyumlarını etkileyen bazı faktörlerin incelenmesi ve polislerin meslek etiği tutumları ile iş doyum düzeyleri arasında bir ilişkinin olup olmadığının araştırılması hedeflenmiştir. Son yıllarda Türk polislerinin iş doyum düzeyleri üzerine önemli sayıda araştırmalar yapılmıştır. Ancak aynı şeyi polis meslek etiği araştırmaları için söylemek mümkün değildir. Ayrıca, ne yerli literatürde ne de yabancı literatürde mesleki etik tutumları ile iş doyum düzeyi arasındaki ilişkiyi araştıran bir çalışmaya rastlanmamıştır. Bu araştırma bu yönleriyle literatürdeki önemli bir boşluğu doldurmak iddiasındadır. Araştırmanın bulgularının, Türk polisinin meslek etiği tutumlarını ve onların iş doyumlarını etkileyen faktörleri daha iyi anlamaya ve bu doğrultuda onların, mesleki etik ilkelerine daha yüksek düzeyde uymalarını sağlamaya ve iş doyumlarını yükseltmeye yardımcı olacağı değerlendirilmektedir.

\section{LITERATÜR TARAMASI}

\section{1. İş Doyumu Araştırmaları}

İş doyumu, üzerine en fazla araştırma yapılan olgulardandır. Bir yıl içerisinde bu konuda yapılan araştırmaların sayısı beş bini geçmektedir (Curtis, 2007). Ülkemizde de iş doyumu üzerine çok sayıda araştırma yapılmıştır ve yapılmaya da devam edilmektedir. Iş doyumu olgusu genellikle motivasyon kuramları çerçevesinde ele alınmakta ve bu kuramlar kullanılarak açıklanmaya çalışılmaktadır. Bu kuramlara; Gereksinim Hiyerarşisi, Varoluş, ilgililik ve Büyüme, Başarma İhtiyacı, Çift Etmen ve Beklenti kuramları örnek olarak verilebilir. Bu kuramlar ışığında işin anlamlııı̆ı, işin kendisi, işin yapısı, işin zorluk derecesi, işin sorumluluğu, iş güvencesi, iş güvenliği, örgütün büyüklüğü ve yapısı, örgüt kültürü, çalışma koşulları, ücret, ödül, yükselme olanakları, hizmet içi eğitim, yönetim (denetim), örgütsel 
destek, iletişim ve sosyal ortam gibi faktörlerin iş doyumu üzerine etkileri incelenmiş ve pek çok araştırma bu faktörlerin iş doyumu üzerine etkilerini onaylamıştır (Ör: Blau, 1964; Bozkurt ve Bozkurt, 2008; Chen, 2008; Curtis, 2007; Çakır, 2001; Çarıkçı, 2000; Davis, 2004; Delice ve Gül, 2012; Edvardson ve Custavsson, 2003; Girgin, 2009; İşcan ve Timuroğlu, 2007; Köroğlu, 2011; Luthans, 1992; Özgen, Öztürk ve Yalçın, 2002; Solmuş, 2004; Spector, 1997; Tengilimoğlu ve Yiğit, 2005). Ancak bu örgütsel faktörlerin, aynı işyerinde çalışan bireyler üzerinde aynı oranda etki etmediği anlaşıldığından (Arvey, Carter ve Buerkley, 1991; Köroğlu, 2011; Sun, 2002) iş doyumu üzerine bireysel faktörlerin etkileri de sıklıkla incelenmiştir. Bu kapsamda işgörenin genetik yapısının, yaşının, cinsiyetinin, medeni durumunun, eğitim seviyesinin, bilgi ve beceri düzeyinin, deneyimlerinin, değerlerinin, yetiştirilme tarzlarının, kişilik yapısının, ihtiyaç ve beklentilerinin iş doyumu üzerine etkileri araştırılmış ve pek çok bilimsel araştırma bu faktörlerin iş doyumunu etkilediğini göstermiştir (Ör. Akıncı, 2002; Barutçugil, 2004; Chen, 2008; Donuk, 2009; Eğinli, 2009; İşcan ve Timuroğlu, 2007; Keser, 2006; Kocabıyık ve Çakıcı, 2008; Okpara, 2006; Özdemir, 2006; Özgen vd., 2002; Özkalp, 2001; Sevimli ve İşcan, 2005; Sığrı ve Basım, 2006; Spector, 1997; Sun, 2002; Tengilimoğlu ve Yiğit, 2005; Yapraklı ve Yılmaz, 2007).

Son yıllarda ülkemizde polisin iş doyum düzeyini ölçen ve polisin iş doyum düzeyini etkileyen faktörleri araştıran çalışmaların sayısı belirgin şekilde artmıştır. Bu araştırmalardan birinde Baştemur (2006) Kayseri'de 361 polisin iş doyumunu incelemiş ve kıdem, rütbe, medeni durum ve eğitim durumu gibi faktörlerin polislerin iş doyumunu etkilediğini bulmuştur. Bir diğerinde Şanlı ve Akbaş (2009) eğitim, operasyonel ve destek birimlerinde çalışan 355 polisin iş doyumunu incelemiş ve yaş, cinsiyet, medeni durum, örgenim durumu, rütbe, mesleki kıdem, alınan takdirnameler ve maddi ödüller (taltif) değişkenlerine göre iş doyum düzeylerinin anlamlı bir farklılık göstermediğini tespit etmiştir. Bununla beraber, eğitim birimlerinde çalışanların ve mesai saatleri daha düzenli olanların iş doyum düzeyinin daha yüksek olduğunu bulmuştur.

Şeker ve Zırhlığlu (2009) ise Van ilinde 1121 erkek ve 93 kadın polisin iş doyumunu incelemiş, Şanlı ve Akbaş'ın (2009) tersine yaşa, medeni duruma, kıdem ve üstler tarafından takdir edilmeye göre iş doyum düzeyinin farklılaştığını bulmuştur. Benzer olarak Okyay (2009) da 270 polisle yaptığı araştırmasında kıdeme göre iş doyumunun farklılaştığını bulmuştur. Bu bulgular kıdem arttıkça iş doyumunun düştüğünü göstermiştir. Çelik ve Duran (2011) Adıyaman ilinde 575 polisle yaptığı araştırmasında polislerin, işini sevme, amirlere karşı tutum memnuniyeti, takdir edilmeye inanma gibi iş doyumunun farklı boyutlarına karşı farklı tutumlar geliştirdiğini ve iş doyumunun yıllara göre farklılık gösteren dinamik bir süreç olduğunu göstermiştir.

Yiğit, Dilmaç ve Deniz (2011) Konya ilinde 680 polisle yaptığı araştırmada genç, kıdemi az, eğitim düzeyi yüksek ve rütbeli polislerin daha yüksek oranda iş doyumuna sahip olduklarını tespit etmişlerdir. Bu bulgular Şeker ve Zırhlıoğlu (2009) ve Okyay'ın (2009) bulguları ile uyuşurken Şanlı ve Akbaş'ın (2009) bulguları ile uyuşmamaktadır. Ayrıca bu araştırmada il merkezinde çalışanların iş doyumlarının ilçede çalışanlardan fazla olduğu, iş doyum düzeyi en düşük olan grubun polis merkezlerinde çalışanlar olduğu bulunmuştur. Akdoğan ve Köse (2012) ise meta analiz yöntemiyle polislerin iş doyumu üzerine yapılmış 39'u yabancı ve 5'i yerli toplam 44 araştırmayı incelemiş ve terfi sistemleriyle rütbeli polis olma faktörlerinin iş doyumu üzerine etkilerini rapor etmişlerdir. Aynı araştırmada bu faktörlerin etkilerinin yıllara, ülkeye ve katılımcı sayısına göre değiştiği de bulunmuştur.

Delice (2014a) farklı birim ve rütbelerden 655 polisle yaptığı araştırmasında polislerin iş doyumunun; çalışma arkadaşları, işin yapısı ve yönetim faktörleri açısından daha yüksek düzeyde olduğunu, ancak terfi, ödüllendirme ve sosyal haklar faktörleri açısından daha düşük düzeyde olduğunu bulmuştur. Polislerin iş doyum düzeyleri ücret, işin yapılma şekli ve çalışma koşulları açısından ise orta düzeydedir. Ayrıca bulgular, polislerin iş doyumunun erkek veya kadın olmaya göre ve evli veya bekâr olmaya göre farklılaşmadığını göstermiştir. Yaş ve kıdem arttıkça ise iş doyum düzeyinin arttığı tespit edilmiştir. Araştırmada, polislerin eğitim seviyesinin onların iş doyumlarını etkilemediği, rütbeli polislerin ise rütbesizlere göre iş doyumlarının daha yüksek olduğu çıkarımı yapılmıştır. Yine bu 
araştırmada Yiğit vd. (2011) ile benzer olarak ilçelerde ve sokakta çalışan polislerin iş doyum düzeylerinin daha düşük olduğu tespit edilmiştir.

Polislerin iş doyumu üzerine yapılmış araştırmalar polislerin iş doyum düzeyinin 100 üzerinden 60 civarında olduğunu, bir diğer deyişle orta düzeyde olduğunu göstermişlerdir (Çelik ve Duran, 2011; Delice, 2014a; Okyay, 2009). Yine bu araştırmaların geneli polislerin, iş doyumunun farklı boyutlarına karşı farklı tutumlar geliştirdiklerini ve polislerin iş doyum düzeylerinin yaş, cinsiyet, medeni durum, kıdem, eğitim seviyesi, rütbe, çalışılan birim gibi demografik değişkenlerden etkilendiğini göstermiştir.

\subsection{Polis Etiği Araştırmaları}

İ̧ doyumu olgusu kadar olmasa da polis etiği olgusu üzerine de sıklıkla araştırmalar yapılmaktadır. Araştırmalar daha çok polis yozlaşması, ihlal edilen etik dışı kurallar, polislerin etik kurallarını algılamaları ve etik eğitimleri üzerine yoğunlaşmaktadır. Araştırmaların bulguları, az veya çok polis yozlaşmasının her ülkede ve her polis teşkilatında görüldüğünü ve yozlaşmanın polis teşkilatlarını olumsuz etkilediğini göstermektedir (Cerrah vd., 2009; IACP, 2012). Ayrıca, polisler birbirlerini koruma eğiliminde olduklarından polis yozlaşmasının göründüğünden çok daha fazla miktarda olduğu tahmin edilmektedir (Ahlf, 2007; French, 2008). ABD ve İngiltere'de yapılan araştırmalarda en sık rastlanan ve halkı en çok rahatsız eden polisin etik dışı davranışların şunlar olduğu bulunmuştur (Greene, Piquero, Hickman ve Lawton, 2004; Rowe, 2007; The Institute for Law Enforcement Administration, 2012): Yetkilerini kötüye kullanıp maddi kazanç elde etme; şüpheliye uygulanan kötü muameleler; etnik ayrımcılık/önyargılar; ırkçı, cinsiyetçi, saldırgan bir dil kullanma; orantısız güç kullanma; dürüst olmama; şüphelinin haklarını vermeme; disiplinsizlik; halka hakaret etme ve görev dışındaki uygunsuz davranışlar.

Polislerin etik algıları üzerine yapılan araştırmalar polislerin, bazı etik dışı davranışları diğer bazılarına göre daha ciddi ve önemli olarak algıladıklarını göstermektedir. Örneğin Chiristine'nin (1994) ABD'de yaptığı bir araştırmaya göre polisler, rüşvet, şüpheli üzerine silah yerleştirme, hırsızlık, uyuşturucu kullanma, bir yardım çağrısına zamanında cevap vermeme, çalıntı bir malı satın alma, yalancı şahitlik, usulsüz rapor (tutanak) düzenleme, orantısız güç kullanımını gizleme, orantısız güç kullanan arkadaşına müdahale etmeme ve görevdeyken cinsel ilişkiye girme gibi etik dışı davranışları diğerlerine göre daha ciddi ve önemli olarak değerlendirmektedir. Tersine, trafik cezasından kurtulmak için kimliğini gösterme, etnik orijininden dolayı bir şahsa hırsı muamelesi yapma, acil bir durum olmamasına rağmen araçla hız yapma, meslektaşına ceza yazmama, yetkisi olmadan kayıtları sorgulama, yetkisi olmadan birisinin üzerini arama, bedava kahve teklifini kabul etme, şüpheliyi durdurup taciz etme, gizli çalışırken önemli bir suç işleme, gizli çalışırken güven kazanmak için uyuşturucu madde kullanma ve görevde uyuma davranışlarını polisler diğer etik dışı davranışlarına göre daha az ciddi ve önemli olarak algılamaktadırlar. Aynı araştırmada polisler, kendi teşkilatlarında bedava kahve/yemek teklifini kabul etme, acil bir durum olmadan hız yapma, trafik cezasından kurtulmak için kimlik gösterme, görevdeyken uyuma, etnik orijininden dolayı bir vatandaşı taciz etme, yetkisi olmadan şüphelinin üzerini arama, orantısız güç kullanma ve bir çağrıya zamanında cevap verememe davranışlarının diğer etik dışı davranışlara göre daha sık yaşandığını belirtmişlerdir. Yine ABD'de Boles (1995) tarafından yapılan araştırma da benzer sonuçlar göstermektedir. Bu araştırmaya göre polislerin \%53'ü polislerin etik kurallara uygun davrandıklarını düşünmektedir. Ancak bulgular, polislerin kendilerini etik olarak algılarken başkalarını daha çok etik dışı algıladıklarını göstermiştir. Polislerin çoğu yalan ifade vermeyi etik bulmazlarken, yaklaşık yarısı yarı fiyatına yemek yemeği etik bulmaktadır.

Polis etiği eğitimleri üzerine yapılan bir araştırmada ise ABD'de polis teşkilatlarının \%80'inin etik eğitimi verdiği ve eğitimlerin özellikle aday memurlara verildiği bulunmuştur (IACP, 2012). Etik eğitimlerinin odaklandıkları konular; etik ilkeler, değerler, karar verme yöntemleri, polis güvenliği teknikleri, orantılı güç kullanımı, gücü ve yetkiyi kötüye kullanmama, yozlaşma, toplumun güvenini kazanma ve kültürel farklılıklar gibi konulardır. 
Türkiye'ye gelince, ülkemizde bilimsel araştırmalarda polis etiği olgusunun nadiren ele alındığ 1 ve özellikle bu olgu üzerine yapılmış alan araştırmalarının sayısının iki elin parmaklarını geçmediği görülmektedir. Bu araştırmalardan birinde Bal ve Beren'in (2003) Ankara'da farklı rütbelerden 657 polisle yaptıkları ve polis yöneticilerinin davranışlarını etik yönünden değerlendirdikleri araştırmada polislerin yaklaşık \%40'ının polis yöneticilerinin polis memurlarını özel işlerinde kullandıklarını, \%10'unun polis yöneticilerin trafik kurallarına uymadıklarını, \%15'inin yöneticilerin yolsuzluklara göz yumduklarını, \%20'sinin yöneticilerin hediye ve rüşvet kabul ettiklerini, \%10'unun yöneticilerin aşırı kuvvet uyguladıklarını ve $\% 18$ 'inin ise polis yöneticilerinin kendilerine yakın gördüklerine ayrıcalıklı davrandıklarını düşündüklerini bulmuşlardır.

Bedük, Erdemir ve Öz (2005) Karaman'da 150 polisle meslek etiği algısı üzerine yaptığı araştırmada polislerin yaklaşık yarısının meslek etiğini ahlaki değerler bütünü olarak ve iyikötü, doğru-yanlış kriterlerinin izahı olarak algıladıklarını tespit etmiştir. Bulgulara göre polislerin algıladıkları en önemli etik ilkeler sırasıyla; doğruluk, tarafsızlık, insanlara saygı, bağlılık, yasaların uygulanması ve halkı korumaktır. Etik dışı olarak görülen en önemli davranışlar ise; ayrımcılık ve kayırmadır. Polisler, hediye kabul etmeyi açık bir etik kuralı ihlali olarak görmektedirler.

Cerrah vd. (2009) Ankara, İstanbul ve İzmir illerinde çalışan 571 trafik polisi ve 486 ticari taksi/minibüs şoförü ile polis yozlaşması üzerine yaptıkları araştırmada polislerin yaklaşık yarısının hem polis okullarında hem de mesleğe başladıktan sonra etik eğitimleri aldıklarını tespit etmişlerdir. Bulgulara göre polislerin yaklaşık yarısı trafik uygulaması yaparken polis arkadaşlarına veya sivilden akraba ve arkadaşlarına ayrım yapmadan davranabileceklerini belirtmişlerdir. Polislerin çoğu (\%67) sürücülerin kendilerine para teklif etmesinin davranışlarını etkilemediğini söylemişlerdir. Polislerin tamamına yakını (\%90) ise rüşvet kabul etmeyi yanlış bulmaktadır. Polislerin yaklaşık yarısı vatandaştan küçük hediyeler alınabileceğini düşünmektedir. Bununla beraber polislerin çoğu hediye alınanlarına ayrımcılık yapılmasını yanlış bulmaktadır. Polislerin yarısından fazlası amirlerinin kendilerini etik dışı davranışlara karşı yeterince denetlemediklerini ifade etmiştir. Polislerin tamamına yakını ise kendi arkadaşlarının yanlış davranışlarda bulunmaları durumunda onları uyardıklarını belirtmişlerdir. Aynı araştırmada sivil vatandaşlardan elde edilen bulgulara göre ise sivillerin az bir kısmı (\%27) trafik denetimlerinde polislerin kendilerine rüşvet teklif ettiğini belirtmişlerdir. Bunların tamamına yakını (\%81) ise teklif edilen bu teklife olumlu yanıt verdiklerini ifade etmiştir. Sivil vatandaşların \%80'i polise rüşvet vermeyi yanlış bulmaktadır. Bir taksi şoförü, trafik polislerinin kendi duraklarına sıklıkla geldiğini ve bu gelişlerde kendilerine ceza yazılmasından korktukları için polislere farklı ikramlarda bulunduklarını söylemiştir. Ayrıca, taksiciler ve ticari minibüs şoförlerinin bir kısmı trafik polislerin kendileriyle uğraşmasından kurtulmak için belirli dönemlerle kendi aralarında para topladıklarını ve bunu mıntıkadaki trafik polislerine verdiklerini iddia etmişlerdir (Cerrah vd., 2009: 6).

Cerrah (2012) mülakat yöntemiyle yaptığı araştırmasında, sayı veya oran vermemekle birlikte, polisin otoritesini usulsüz kullanması, esnaftan bedava yemek yemesi, polislik ve şahsı hizmetleri bedava yaptırması, polis amirlerinin etraftan hediye kabul etmesi, küçük veya büyük miktarlarda rüşvet alınması gibi etik dışı davranışların örneklerini aktarmıştır. Yazar, esnafın memnun görünmesine rağmen aslında polise yaptığı karşılıksız ikramlardan hoşnut olmadığını vurgulamıştır. Polisin ise bu ikramları kendi hakkı olarak algıladığını belirtmiştir. Bununla beraber yazar, milyonlarca lira rüşvet teklif edilmiş olmasına rağmen veya yaptığı görev gereği eline çıkar temin etme fırsatı geçmiş olmasına rağmen bunlara aldııış etmeden hakkıyla görevini yapmış polislerden de alıntılar yapmıştır. Bunların da sayı ve oranları ile ilgili bir veri sunulmamıştır.

Delice (2014b) ise farklı rütbelerdeki 484 polisle yaptığı araştırmada polislerin büyük çoğunluğunun polis eğitim kurumlarında etik eğitimi almalarına rağmen bunların meslek içinde bu eğitimi yeniden almadığını bulmuştur. Bulgulara göre etik eğitimi almış olmalarına rağmen polislerin 
yarısına yakını polis etiği kurallarının mantıklı ve uygulanabilir olmadığını ve değişmesi gerektiğini ifade etmişlerdir. Yukarıda sıralanan araştırmalarla (Bal ve Beren, 2003; Boles, 1995; Cerrah vd., 2009; Chiristine, 1994; IACP, 2012) benzer olarak bu araştırmada da polislerin rüşvet alınması, olay yerindeki kıymetli eşyanın cebe atılması, suç kayıtlarının değiştirilmesi, görevliyken erkek polisin bayan astının rızasız yüzünü okşaması, şüphelinin üzerine sonradan silah yerleştirilmesi, bir olayla ilgili yanlış bir olay yeri tutanağı hazırlanması gibi davranışların polisler tarafından daha ciddi ve önemli etik dışı davranışlar olarak algılandıkları bulunmuştur. Benzer olarak; polislerin acil bir durum olmamasına rağmen hız sınırı üzerinde araç kullanması, küçük hediyelerin kabul edilmesi, trafik cezasından kurtulabilmek için polis kimliğinin gösterilmesi, gizli çalışan narkotik polisinin uyuşturucu çetesinin güvenini kazanmak için kokain kullanması, suçları önlemek için sokakta insanların üzerinin rastgele aranması, hırsızlık sabıkalııının sokakta nedensiz üzerinin aranması, meslektaşların korunması gibi etik dışı davranışların ise polisler tarafından tolare edildiği ve ciddi ve önemli bir sorun olarak algılanmadığı bulunmuştur. Bulgulara göre polisler, ciddi olarak algıladıkları etik dışı davranışların polis teşkilatında nadiren yaşandığını, önemsiz olarak gördükleri etik dışı davranışların ise diğerlerine oranla daha sık yaşandığını düşünmektedirler. Araştırmada polislere sunulan 45 senaryo konularına göre gruplandığında polislerin yeterli polislik hizmeti sağlanamaması türündeki etik dışı davranışları daha ciddi ve önemli olarak algıladıkları, buna rağmen bireysel hakların ihlali türündeki etik dışı davranışları ise daha düşük düzeyde ciddi ve önemli olarak algıladıkları ortaya çıkarılmıştır. Etik algıların polislerin demografik özelliklerine göre değişip değişmediğine bakıldığında ise meslek etiği algılarının sadece yaş, kıdem ve rütbe değişkenlerine göre anlamlı düzeyde farklılaştığı bulunmuştur. Cinsiyet, medeni hal, eğitim seviyesi, çalışılan birim, okulda alınan etik eğitimi ve hizmet içi eğitimlerdeki etik eğitimi değişkenleri polislerin etik algıları üzerinde bir etki yaratmamaktadır. Genç ve rütbesiz polislerin etik dışı davranışları daha düşük düzeyde ciddi ve önemli olarak algıladıkları bulunmuştur.

Delice (2014c) yukarıda sonuçları aktarılan meslekteki polislerle yaptığı araştırmasını Polis Meslek Yüksek Okulunda eğitim gören 220 polis adayı ile tekrarlamıştır. Bulgular önceki araştırmayla benzer olarak, benzer davranışların daha ciddi ve önemli etik dışı davranışlar ve yine benzer davranışların daha az ciddi ve önemsiz etik dışı davranışlar olarak algılandıklarını göstermiştir. Yine polis adayları çalışan polislerle benzer olarak, önemli ve ciddi olarak algılanan etik dışı davranışların daha az sıkıkla, daha az önemli ve ciddi olarak algılanan davranışların ise daha fazla sıklıkla yaşandığını düşünmektedirler. Bu araştırmada polis adaylarının meslek etiği algılarının yaşa, anne eğitim seviyesine, baba eğitim seviyesine ve ailenin gelir seviyesine göre değişmediği bulunmuştur.

Yukarıda özetlenen araştırmalardan Türk Polis Teşkilatında yozlaşma örneklerinin görüldüğü, bu etik dışı davranışlara karşı polislerin farklı tutumlar geliştirdiği, geliştirilen bu tutumların ise polis yozlaşması üzerinde etkilerinin olabileceği anlaşıımaktadır. Yine bu araştırmalar polislerin etik algılarının onların demografik özelliklerinden nispeten de olsa etkilendiğini göstermektedir. Son olarak, araştırmalar polislerin etik eğitimi aldıklarını, ancak bu eğitimlerin onların algıları üzerinde mutlak bir etkisinin olmadığını da göstermektedir.

\section{YÖNTEM}

Bu araştırmada nicel bir araştırma dizaynı kullanılmıştır. Veriler, hizmet içi eğitimler için bir araya gelmiş farklı yaş, cinsiyet ve birimdeki polis memurlarından anket yöntemiyle toplanmıştır. İş doyumu verileri 20 soruluk kısa Minnesota ölçeğiyle toplanmıştır. Etik algısı verileri ise Delice (2014b) tarafından geliştirilen ölçek ile toplanmıştır. Bu ölçekte polislik mesleğiyle alakalı etik dışı davranışların örneklendirildiği 45 senaryo bulunmaktadır. Bu 45 senaryo; bireysel hakların ihlali, iş düzenini bozma (disiplinsizlik), polisiye yetkilerin kötüye kullanılması, amirin yetkisini kötüye kullanması ve yeterli polislik hizmeti sağlanamaması olmak üzere beş ana türdeki etik dışı davranışlardır. Ölçekte, katılımcılardan bu 45 senaryoyu üç farklı şekilde değerlendirilmeleri istenmiştir. Birinci değerlendirmede 1 ile 10 arasında bir derecelendirmeyle katılımcılar senaryoda sunulan etik dışı davranışın ne kadar ciddi ve önemli olduğunu belirlemişlerdir. ikincisinde, 1 ile 8 arasında ve Polis 
teşkilatı Disiplin Tüzüğüne uygun bir derecelendirmeyle katılımcılar etik dışı davranışa hangi düzeyde bir cezanın verilmesi gerektiğini belirlemişlerdir. 1 "hiçbir ceza verilmemelidir" karşıı̆ı̆ı iken, 8 "memuriyetten çıkarılmalıdır" karşıı̆ı̆ıı. Üçüncüsünde ise, 1 ile 5 arasında bir derecelendirmeyle katılımcılar etik dışı davranışın teşkilatta hangi sıklıkla yaşandığı hakkındaki düşüncelerini belirtmişlerdir. 1 "hiçbir zaman" karşılığı iken, 5 "her zaman" karşılı̆̆ıdır. Anketlerle elde edilen veriler SPSS 17.0 programında betimsel istatistikler, t-test, ANAVO ve Pearson Product Moment Korelasyon testleri kullanılarak analiz edilmiştir.

\section{BULGULAR}

Tablo1: Katılımcıların Demografik Özellikleri

\begin{tabular}{lcc}
\hline Değişken & $\mathbf{n}$ & \% \\
\hline Yaş (M = 30,0, Ss = 7,5) & & 59,2 \\
$20-30$ & 181 & 31,0 \\
$31-40$ & 95 & 9,8 \\
$41-60$ & 30 & 96,1 \\
Cinsiyet & & 3,9 \\
Erkek & 299 & 35,8 \\
Kadın & 12 & 63,8 \\
Medeni Hal & & \\
Bekâr & 110 & 45,7 \\
Evli & 196 & 35,0 \\
Kıdem (M = 7,3, Ss =6,6) & & 19,3 \\
$1-5$ Yıl & 137 & \\
6-10 Yıl & 105 & 58 \\
11 Yıl ve Üzeri & & \\
\hline
\end{tabular}

$\mathrm{N}=314$

Tablo 1'de araştırmaya katılan 314 polisin demografik bilgileri sunulmuştur. Katılımcıların tamamı polis memurudur. Yaş ortalaması 30'dur ve araştırmaya katılanların yarısından fazlası 20-30 yaşlarında genç polislerdir. Katılımcıların sadece $\% 3,9^{\prime} u$ kadındır. Kadın polis oranı düşük gibi görünse de bu oran polis teşkilatının genelindeki \%4,5'luk kadın polis oranına oldukça yakındır (EGM, 2013). Bekâr katılımcıların oranı \%35,8 iken evlilerin oranı 63,8'dir. Polis teşkilatında çalışılan yıl sayısına bakıldığında ise katılımcıların yarısına yakının $(\% 45,7) 1-5$ yıldır polis olduğu, toplamda ise yaklaşık \%80'inin 10 yıl ve daha az süredir polis teşkilatında bulunduğu anlaşılmaktadır. 
Tablo 2: İ̧ Doyumunu Etkileyen Faktörler ve Bunlara Iliş̧in Memnuniyet Düzeyleri

\begin{tabular}{lcc} 
Değişken & Ortalama & SS \\
\hline Başkaları i̧̧in bir şeyler yapabilme imkânı & 4,0 & 0,9 \\
Toplumda saygınlık sağlama & 3,9 & 0,9 \\
Yetki düzeyi & 3,8 & 0,8 \\
Çalışma arkadaşları & 3,8 & 0,9 \\
Elde edilen başarma duygusu & 3,8 & 1,0 \\
İşin inanç ve değerlere uygunluğu & 3,8 & 1,0 \\
İ̧̧ güvencesi & 3,8 & 1,1 \\
İşin işgörenin niteliklerine uygunluğu & 3,6 & 1,1 \\
Bilinenden farklı şekilde iş yapabilme imkânı & 3,3 & 1,0 \\
Takdir edilme & 3,1 & 1,2 \\
Ücret düzeyi & 3,1 & 1,3 \\
İşgören usulünde çalışma imkânı & 3,0 & 1,1 \\
İşgörenin yeteneklerini kullanabilme imkânı & 2,9 & 1,2 \\
Kararların uygulamaya konulması tarzı & 2,8 & 1,1 \\
Kararlara katılma olanağı & 2,7 & 1,2 \\
Amirlerin idare tarzı & 2,6 & 1,2 \\
Amirlerin karar verme yeteneği & 2,6 & 1,2 \\
İşin getirdiği meşguliyet & 2,5 & 1,2 \\
Terfi olanakları & 2,3 & 1,2 \\
Çalışma şartları & 2,3 & 1,3 \\
\hline ORTALAMA DEĞER & 3,2 & 0,6 \\
\hline N & &
\end{tabular}
$\mathrm{N}=299$

Tablo 2'de iş doyumunun 20 farklı boyutuna ait düzeyler sunulmuştur. Bulgulara göre doyum düzeyleri 2,3 ila 4,0 arasında farklılaşmaktadır. Bu değerler, 2,4 ve altında olması durumunda katıımcıların memnun olmadığı, 2,5 ile 3,4 aralığında olması durumunda kararsız oldukları ve 3,5 ve üzerinde olması durumunda da memnun oldukları şeklinde anlaşılır. Bu 20 farklı boyutun genel ortalaması 3,2' dir. Bir diğer deyişle, katılımcıların ortalama iş doyumu 100 üzerinden 64'tür. Dolayısıyla katılımcıların işlerinden tam olarak memnun olmadıkları, işlerinden memnuniyetleriyle ilgili kararsız oldukları söylenebilir. Katılımcıların işleriyle ilgili en çok memnun oldukları beş boyut sırasıyla şunlardır: İşlerini yaparken başkaları için bir şeyler yapabilme imkânı $(4,0)$, işlerinin kendilerine toplumda bir saygınlık sağlaması $(3,9)$, işlerinde sahip oldukları yetki düzeyi $(3,8)$, iş yerinde çalışma arkadaşlarıyla geliştirdikleri sosyal ortam $(3,8)$ ve işlerinden elde ettikleri başarma duygusu $(3,8)$. Bu alanların doyum düzeyi 4'e yakındır ve iş doyum ölçeğinde bu değer "memnunum" ifadesini karşıladığı için katılıcıların bu boyutlar açısından memnun oldukları söylenebilir. Katılımcıları işleriyle alakalı en az memnun eden beş boyut ise sırasıyla şunlardır: İ̧̧ yerindeki çalışma şartları $(2,3)$, terfi olanakları $(2,3)$, işin getirdiği meşguliyet miktarı $(2,5)$, amirlerin karar verme yeteneği $(2,6)$ ve amirlerin idare tarzı $(2,6)$. Bu alanların doyum düzeyi 2 ve 3 arasındadır ve iş doyum ölçeğinde bu değerler "memnun değilim" veya "kararsızım" ifadelerinin karşılığı olduğundan bu boyutlarla ilgili olarak katılımcıların ya memnun olmadıkları ya da kararsız oldukları söylenebilir. 
Tablo 3: Meslek Etiği Algı Düzeylerinin Demografik Değişkenlere Göre Farklılaşma Analizi

\begin{tabular}{llc}
\hline Değişken & & Ortalama iş Doyumu \\
\hline Yaş & & 3,2 \\
$20-30$ & & 3,1 \\
$31-40$ & $F$ & 3,5 \\
$41-60$ & & $3,7^{*}$ \\
& & \\
Cinsiyet & $t$ & 3,2 \\
Erkek & & 3,2 \\
Kadın & & 0,2 \\
& & \\
Medeni Hal & $t$ & 3,2 \\
Bekâr & & 3,2 \\
Evli & & 0,2 \\
& & \\
Kıdem & $F$ & 3,2 \\
1-5 Yıl & & 3,0 \\
6-10 Yıl & & 3,3 \\
11 Yıl ve Üzeri & & $5,5^{* *}$ \\
\hline
\end{tabular}

*. Değişkenler arasındaki ilişki 0,05 seviyesinde anlamlıdır.

**. Değişkenler arasındaki ilişki 0,01 seviyesinde anlamlıdır.

Tablo 3'te katılımcıların iş doyum düzeylerinin demografik değişkenlere göre nasıl farklılaştığı gösterilmiştir. Bulgulara göre cinsiyet ve medeni hal değişkenleri açısından katılımcıların memnuniyet düzeyleri farklılaşmamaktadır. Bir diğer deyişle, erkek veya kadın, evli veya bekâr fark etmez katılımcılar işlerinden benzer düzeyde memnuniyet duymaktadırlar. Diğer yandan bulgular, yaş ve kıdem değişkenleri açısından katılımcıların memnuniyet düzeylerinin farklılaştığını göstermektedir. ANOVA testinde Post Hoc analizleri 41-60 yaş grubu katılımcıların diğer yaş gruplarına göre işlerinden daha yüksek düzeyde memnun olduklarını göstermiştir. Post Hoc analizleri, kıdem değişkeni açısından ise fark yaratan grubun 6-10 yıl kıdeme sahip olanlar olduğunu göstermiştir. Bulgulara göre 1-5 yıl kıdeme sahip olanlarla 11 yıl ve üzeri kıdeme sahip olanların memnuniyet düzeyleri arasında istatistiki olarak anlamlı bir farklılık bulunmazken 6-10 yıl kıdeme sahip olanların memnuniyet düzeyi diğer iki grubun memnuniyet düzeyinden anlamlı olarak daha düşüktür.

Tablo 4'te polis meslek etiğinin farklı boyutlarını örneklendiren 45 senaryonun katılımcılara ait değerlendirmeleri beş ana grup içinde sunulmuştur. Tabloda, senaryolarla ilgili yapılan değerlendirmeler ciddiyet derecesi, bu etik dışı davranışa verilmesi gereken ceza düzeyi ve bu etik dışı davranışın teşkilatta tahminen hangi sıklıkla yaşandığı başlıkları altında üç farklı sütunda ayrı ayrı gösterilmiştir. Elde edilen bulgulara göre katılımcıların en ciddi gördüğü veya polisin kesinlikle yapmaması gerektiğini düşündükleri 10 davranış sırasıyla şöyledir: Rüşvet alınması $(9,7)$, olay yerindeki kıymetli eşyanın cebe atılması $(9,4)$, suç kayıtlarının değiştirilmesi $(9,4)$, ceza yazılması gereken sürücünün cezanın yarısı kadar rüşvetle salıverilmesi $(9,2)$, görevliyken erkek polisin bayan astının rızasız yüzünü okşaması $(9,2)$, görevdeyken içki içilmesi $(8,9)$, şüphelinin üzerine sonradan silah yerleştirilmesi $(8,9), 4-5$ bardak bedava içki için içkili mekâna işlem yapılmaması $(8,9)$, bir olayla ilgili yanlış bir olay yeri tutanağı hazırlanması $(8,8)$ ve polis yöneticisinin makam arabasını ve şoförünü özel işlerinde kullanması $(8,8)$. Katılımcıların bu davranışları en yüksek değer olan 10 değerine yakın bir düzeyde ciddi ve önemli görmüş olmaları dikkat çekicidir.

Katılımcıların meslek etiği açısından en az ciddi gördükleri veya en düşük düzeyde bir sorun olarak algıladıkları etik dışı 10 davranış ise sırasıyla şöyledir: Trafik cezasından kurtulabilmek için polis kimliğinin gösterilmesi $(4,6)$, acil bir durum olmamasına rağmen hız sınırı üzerinde araç kullanılması 
$(4,8)$, göreve yeni başlayan polis amirinin esnafın çiçek ve çikolata hediyelerini kabul etmesi $(4,9)$, uğraşılarak yakalanan hırsızlık şüphelisine bir iki yumruk atılması $(5,1)$, suçları önlemek için sokakta insanların üzerinin rastgele aranması $(5,3)$, gizli çalışan narkotik polisinin uyuşturucu çetesinin güvenini kazanmak için kokain kullanması $(5,3)$, hırsızlık sabıkalısının sokakta nedensiz üzerinin aranması $(5,6)$, komşunun karıştığı darp olayı hakkında işlem yapılmaması $(5,8)$, uyuşturucudan sabıkası olan vatandaşın izinsiz arabasının aranması $(5,9)$ ve polis yöneticisinin emniyet hizmetlerinde kullanılmak üzere esnafın yardımlarını kabul etmesi $(6,0)$. Bu etik dışı davranışlara ise katılımcılar tarafından orta düzeyde bir önem ve ciddiyet atfedildiği görülmektedir.

Katılımcılara sunulan 45 senaryonun gruplandığı beş ana etik dışı davranış türüne baktığımızda katılımcıların, yeterli polislik hizmeti sağlanamaması $(7,8)$ türündeki etik dışı davranışları en ciddi ve önemli olarak gördükleri anlaşılmaktadır. En az ciddi gördükleri davranış türü ise bireysel hakların ihlali $(7,0)$ türündeki davranışlardır. Diğer üç türdeki davranışların ciddiyet derecesi ortalamalarının ise birbirine yakın olduğu görülmektedir (amirin yetkisini kötüye kullanması $=7,4$, yetkisini kötüye kullanma $=7,4$ ve iş düzenini bozma $=7,2$ ).

Katılımcıların, etik dışı davranışların nasıl cezalandırılması gerektiğiyle ilgili değerlendirmelerine gelince, Tablo 4'teki bulgulara göre en ağır şekilde cezalandırılması gereken davranışlar sırasıyla şöyledir: Rüşvet alınması $(6,8)$, olay yerindeki kıymetli eşyanın cebe atılması $(6,4)$, suç kayıtlarının değiştirilmesi $(6,2)$, ceza yazılması gereken sürücünün cezanın yarısı kadar rüşvetle salıverilmesi $(6,2)$, görevliyken erkek polisin bayan astının rızasız yüzünü okşaması $(5,9)$, şüphelinin üzerine sonradan silah yerleştirilmesi $(5,7)$, görevdeyken cinsel ilişkiye girilmesi $(5,7)$, görevdeyken içki içilmesi $(5,6), 4-5$ bardak bedava içki için içkili mekâna işlem yapılmaması $(5,4)$ ve bir tamirciye araç yönlendirip oradan komisyon alınması. $(5,2)$. En yüksek düzeyde ceza öngörülen davranışlar ve bu davranışların sıralaması ile en ciddi görülen davranışlar ve bunların sıralaması arasında büyük bir benzerlik vardır. Tablo 5 'te sunulan korelasyon analizi bulguları da bu ilişkiyi doğrulamakta ve ciddiyet düzeyi ile verilmesi gereken ceza düzeyi arasında pozitif yönlü, güçlü ve anlamlı bir ilişki olduğunu göstermektedir $(r=0,41, p<0,01)$.

Tablo 4: Katılımcıların Polis Meslek Etiğinin Farklı Boyutlarına Ait Algı Düzeyleri

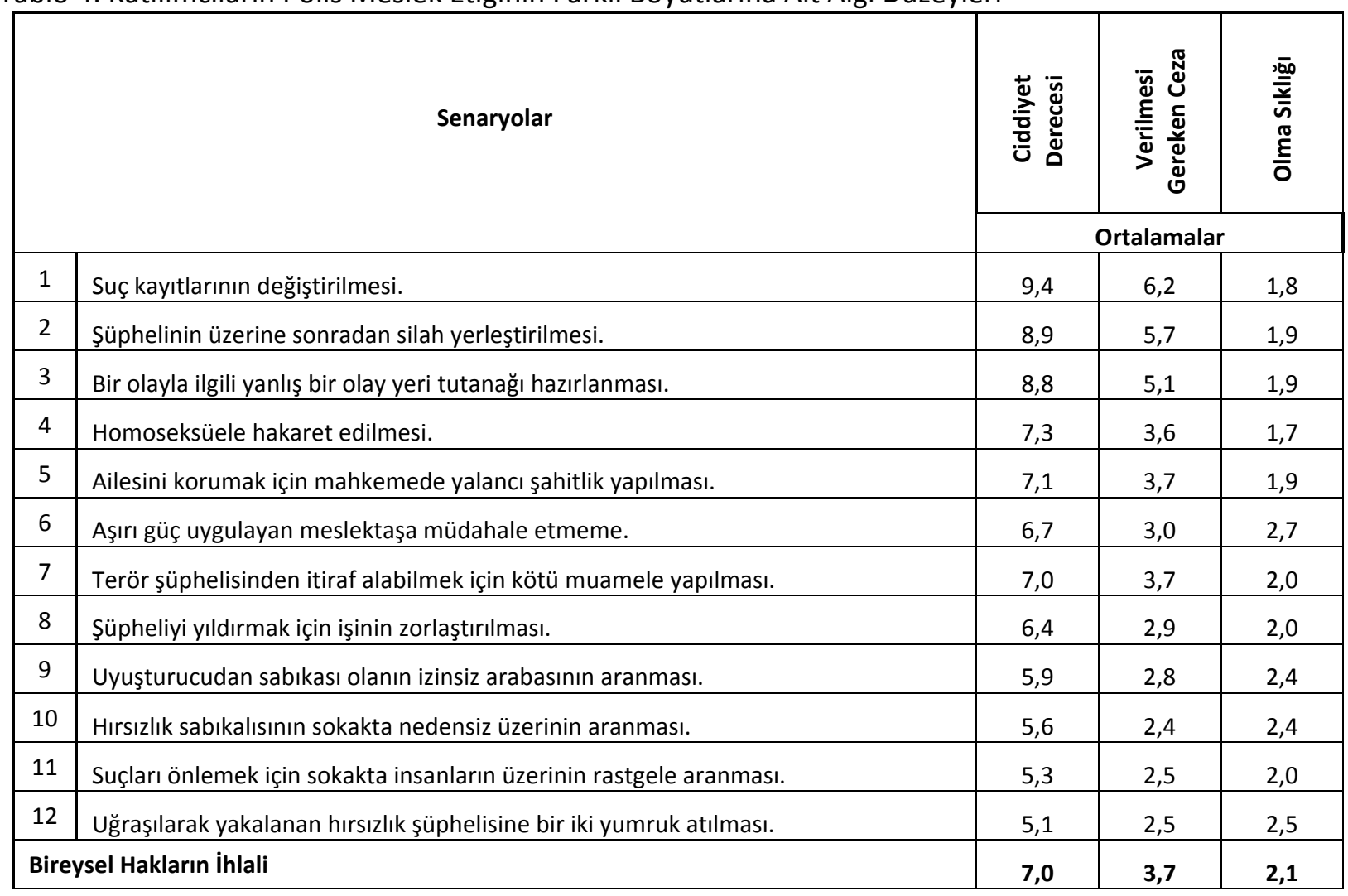


İş Doyumu Ve Meslek Etiği Tutumu Üzerine Bir Araştırma: İş Doyumu İle Etik Tutum Arasında Bir İlişsi Var mı?

\begin{tabular}{|c|c|c|c|c|}
\hline 13 & Görevliyken erkek polisin, bayan astının rızasız yüzünü okşaması. & 9,2 & 5,9 & 1,6 \\
\hline 14 & Görevdeyken içki içilmesi. & 8,9 & 5,6 & 1,9 \\
\hline 15 & Görevdeyken, kadın erkek iki polisin cinsel ilişkiye girmesi. & 8,6 & 5,7 & 1,6 \\
\hline 16 & İşle ilgili hataları örtmek için yalan söylenmesi. & 7,9 & 4,0 & 2,2 \\
\hline 17 & Görevdeyken uyunması. & 6,4 & 3,3 & 2,3 \\
\hline 18 & Acil durum olmamasına rağmen kırmızı ışıkta geçilmesi. & 6,0 & 2,6 & 2,3 \\
\hline 19 & Uyuşturucu çetesinin güvenini kazanmak için kokain kullanılması. & 5,3 & 2,2 & 2,1 \\
\hline 20 & Acil durum olmamasına rağmen hız sınırı üzerinde araç kullanması. & 4,8 & 2,1 & 2,7 \\
\hline \multicolumn{2}{|r|}{ İş Düzenini Bozma (Disiplinsizlik) } & 7,2 & 4,1 & 2,1 \\
\hline 21 & Rüşvet alınması. & 9,7 & 6,8 & 2,1 \\
\hline 22 & Olay yerindeki kıymetli eşyanın cebe atılması. & 9,4 & 6,4 & 1,6 \\
\hline 23 & Hatalı sürücünün cezanın yarısı kadar bir rüşvetle salıverilmesi.. & 9,2 & 6,2 & 2,0 \\
\hline 24 & 4-5 bardak bedava içki için içkili mekana işlem yapılmaması & 8,9 & 5,4 & 1,9 \\
\hline 25 & Bir tamirciye araç yönlendirip oradan komisyon alınması. & 8,6 & 5,2 & 1,8 \\
\hline 26 & Kar edebilmek için bilindiği halde çalıntı eşya satın alınması. & 8,5 & 4,9 & 1,8 \\
\hline 27 & Hatalı olduğu halde zengin sürücüye ceza yazılmaması. & 8,1 & 3,9 & 2,9 \\
\hline 28 & Mıntıkadaki restoranlardan bedava yemek yenilmesi. & 7,3 & 3,4 & 2,9 \\
\hline 29 & Alkollü araç kullanan başka bir polisin hakkında işlem yapılmaması. & 7,0 & 3,5 & 1,9 \\
\hline 30 & Hırsızıık mağdurlarının kendi güvenlik ürünleri dükkânına yönlendirilmesi. & 6,9 & 3,4 & 1,8 \\
\hline 31 & Hatalı olduğu halde akraba olan sürücüye ceza yazılmaması. & 6,4 & 3,0 & 2,8 \\
\hline 32 & Sivilden arkadaşın park cezasının iptal ettirilmesi. & 6,3 & 3,2 & 2,2 \\
\hline 33 & Sivilden arkadaşa polisiye hizmetlerde öncelik tanınması. & 6,3 & 2,9 & 2,2 \\
\hline 34 & Komşunun karıştığı darp olayı hakkında işlem yapılmaması. & 5,8 & 2,6 & 2,5 \\
\hline 35 & Trafik cezasından kurtulabilmek için polis kimliğinin gösterilmesi. & 4,6 & 2,2 & 2,9 \\
\hline \multicolumn{2}{|r|}{ Yetkisini Kötüye Kullanma } & 7,4 & 4,1 & 2,2 \\
\hline 36 & Makam arabasının ve şoförünün özel işlerde kullanılması. & 8,8 & 4,6 & 3,4 \\
\hline 37 & Makamını kaybetmemek için torpil baskılarına razı olması. & 8,6 & 4,7 & 3,5 \\
\hline 38 & Kişisel menfaat elde etmek için emrindekilere ayrıcalık sağlaması. & 8,4 & 4,4 & 2,4 \\
\hline 39 & Şube işleri için esnafın yardımlarını kabul etmesi. & 6,0 & 3,0 & 2,4 \\
\hline 40 & Göreve başlandığında esnafın çiçek ve çikolatalarının kabul edilmesi. & 4,9 & 2,3 & 3,1 \\
\hline \multicolumn{2}{|c|}{ Amirin Yetkisini Kötüye Kullanması } & 7,4 & 3,8 & 2,9 \\
\hline 41 & Asayiş ekibinin trafik olayına müdahaleden kaçınması. & 8,0 & 3,9 & 2,0 \\
\hline 42 & Trafik ekibinin asayiş olayına müdahaleden kaçınması. & 8,0 & 3,6 & 2,0 \\
\hline 43 & Hırsızlık olacağına ilişkin şüphe varken görmezden gelinmesi. & 7,9 & 3,6 & 1,8 \\
\hline 44 & Devriye görevinde mıntıka ayrımı yapılması. & 7,7 & 3,5 & 1,9 \\
\hline 45 & Yaralanmak korkusuyla kavgaya müdahale edilmemesi. & 7,4 & 3,8 & 2,0 \\
\hline \multicolumn{2}{|c|}{ Yeterli polislik hizmeti sağlanamaması } & 7,8 & 3,7 & 1,9 \\
\hline \multicolumn{2}{|c|}{ GENEL } & 7,3 & 3,9 & 2,3 \\
\hline
\end{tabular}


Katılımcıların, en düşük düzeyde cezalandırılması gerektiğini düşündükleri etik dışı davranışlar ise sırasıyla şöyledir: Trafik cezasından kurtulabilmek için polis kimliğinin gösterilmesi $(2,1)$, acil bir durum olmamasına rağmen hız sınırı üzerinde araç kullanılması $(2,2)$, göreve yeni başlayan polis amirinin esnafın çiçek ve çikolata gibi hediyelerini kabul etmesi $(2,3)$, uğraşılarak yakalanan hırsızlık şüphelisine bir iki yumruk atılması $(2,5)$, suçları önlemek için sokakta insanların üzerinin rastgele aranması $(2,5)$, gizli çalışan narkotik polisinin uyuşturucu çetesinin güvenini kazanmak için kokain kullanması (2,2), hırsızlık sabıkalısının sokakta nedensiz üzerinin aranması $(2,4)$, acil durum olmamasına rağmen kırmııı ışıkta geçilmesi $(2,6)$, komşunun karıştığı darp olayı hakkında işlem yapılmaması $(2,6)$ ve uyuşturucudan sabıkası olan vatandaşın izinsiz arabasının aranması $(2,8)$. Benzer olarak, en düşük düzeyde ceza öngörülen davranışlar ve bu davranışların sıralaması ile en düşük düzeyde ciddi görülen davranışlar ve bunların sıralaması neredeyse aynıdır.

Verilmesi gereken ceza değişkeni açısından beş ana türdeki etik dışı davranış sıralamasına baktığımızda en yüksek düzeyli cezalar, yetkisini kötüye kullanma $(4,1)$ ve iş düzenini bozma (disiplinsizlik) $(4,1)$ türündeki etik dışı davranışlar için öngörülmüştür. En düşük düzeyli cezalar ise yeterli polislik hizmeti sağlanamaması $(3,7)$ ve bireysel hakların ihlali $(3,7)$ türündeki etik dışı davranışlar için öngörülmüştür. Yeterli polislik hizmeti sağlanamaması türündeki davranışların katılımcılar tarafından en ciddi ve önemli etik dışı davranışlar olarak görüldükleri hatırlandığında bu türdeki davranışlara en düşük düzeyli cezaların öngörülmüş olması dikkat çekicidir.

Sunulan 45 senaryoyla ilgili katılımcıların yaptığı son değerlendirmeler etik dışı davranışların polis teşkilatında hangi sıklıkla yaşandığıyla ilgilidir. Tablo 4'te sunulan bulgulara göre katıımcıların teşkilatta en sık yaşandığını düşündüğü etik dışı davranışlar sırasıyla şöyledir: Polis amirinin makamını kaybetmemek için torpil baskılarına razı olması $(3,5)$, polis amirinin makam arabasını ve şoförünü özel işlerinde kullanması $(3,4)$, göreve yeni başlayan polis amirinin esnafın çiçek ve çikolata gibi hediyelerini kabul etmesi $(3,1)$, trafik cezasından kurtulabilmek için polis kimliğinin gösterilmesi $(2,9)$, mıntıkadaki restoranlardan bedava yemek yenilmesi $(2,9)$, hatalı olduğu halde zengin sürücüye ceza yazılmaması $(2,9)$, hatalı olduğu halde akraba olan sürücüye ceza yazılmaması $(2,8)$, aşırı güç uygulayan meslektaşa müdahale edilmemesi $(2,7)$, acil durum olmamasına rağmen hız sınırı üzerinde araç kullanması $(2,7)$ ve komşunun karıştığı darp olayı hakkında işlem yapılmaması $(2,5)$. Bu davranışlar için katıımcıların yaptığı değerlendirmelerin ortalaması 3 civarındadır. Bu da ölçekte "bazen" ifadesine denk gelmektedir. Bir diğer deyişle katılımcılar bu davranışların teşkilatta bazen yaşandığını düşünmektedirler. En sık yaşandığı düşünülen etik dışı davranışlara bakıldığında bunların bazılarının katılımcılar tarafından ciddiyet derecesi düşük etik dışı davranışlar olarak değerlendirildikleri anlaşılmaktadır. Bu iki değiş̧ken arasındaki ilişki düzeyine baktığımızda Tablo 5 'teki bulgular bu iki değişken arasında negatif yönlü, zayıf ancak anlamlı bir ilişki olduğunu göstermektedir $(r=-0,12, p<0,05)$. Bir diğer deyişle, katılımcılar daha ciddi ve önemli olarak değerlendirdikleri etik dışı davranışların teşkilatta daha nadir yaşandığını düşünmektedirler.

Tablo 5: Değişkenler Arası Korelasyon ( $r$ ) Analizi

\begin{tabular}{lcc} 
& & \\
Değişken & Ciddiyet Derecesi & Verilmesi Gereken \\
& Ceza & Olma Sıklığı \\
\hline
\end{tabular}

Ciddiyet Derecesi 1

Verilmesi Gereken Ceza

$0,41^{* *}$

1

Olma Sıklığı

$-0,12 *$

0,1

1

*. Değişkenler arasındaki ilişki 0,05 seviyesinde anlamlıdır.

**. Değişkenler arasındaki ilişki 0,01 seviyesinde anlamlıdır. 
En nadir rastlanan etik dışı davranışlar ise katılımcılar tarafından sırasıyla şu şekilde belirlenmiştir: Görevdeyken erkek polisin bayan astının rızasız yüzünü okşaması $(1,6)$, görevdeyken kadın ve erkek iki polisin cinsel ilişkiye girmesi $(1,6)$, olay yerindeki kıymetli eşyanın cebe atılması $(1,6)$, homoseksüele hakaret edilmesi $(1,7)$, suç kayıtlarının değiştirilmesi $(1,8)$, kâr edebilmek için bilindiği halde çalıntı bir eşyanın satın alınması $(1,8)$, hırsızlık olacağına ilişkin şüphe varken görmezden gelinmesi $(1,8)$, bir polisin hırsızlık mağdurlarını kendi güvenlik ürünleri dükkânına yönlendirilmesi $(1,8)$ bir tamirciye araç yönlendirip oradan komisyon alınması $(1,8)$ ve şüphelinin üzerine sonradan silah yerleştirilmesi (1,9). En nadir rastlanan 10 etik dışı davranışın değerlendirme ortalamalarına bakıldığında bunların 2'ye yakın olduğu görülmektedir ki bu değerlendirmeler bu davranışların teşkilatta "nadiren" yaşandığının düşünüldüğünü gösterir. Ayrıca bu davranışlar ciddiyet derecesi yüksek olarak değerlendirilen davranışlardan olduğundan, ciddi etik dışı davranışlar olarak algılanan davranışların genelde nadir yaşandığını da göstermektedir.

Tablo 6'da beş ana türdeki etik dışı davranış değişkenleri kullanılarak katılımcıların bu davranışlara ilişkin ciddiyet düzeyi algılarının demografik değişkenlere göre nasıl farklılaştığı gösterilmiştir. Bulgulara göre katılımcıların yaş ve kıdemleri farklılaşsa da onların beş ana türdeki etik dışı davranışlar açısından ciddiyet veya önem algı düzeyleri farklılaşmamaktadır. Bir diğer deyişle, her yaş ve kıdem grubundaki katılımcılar etik dışı davranışların ciddiyet düzeyi hakkında benzer görüşlere sahiptirler. Cinsiyet değişkeni açısından baktığımızda, kadınların erkeklere göre beş ana gruptaki davranışların tamamında etik dışı davranışlara karşı daha ciddi tutumlar geliştirdiği görülmektedir. Ve bu farklılık bireysel hakların ihlali, iş düzenini bozma ve yeterli polislik hizmeti sağlayamama türündeki etik dışı davranış türleri açısından istatistiki olarak anlamlı düzeydir. Medeni hal değişkeni açısından baktığımızda ise bekâr katılımcıların beş ana türdeki davranışların tamamı açısından evlilere göre etik dışı davranışlar için daha ciddi tutumlar geliştirdiği görülmektedir. Ancak beş davranış türü içerisinde sadece iki tanesi için (iş düzenini bozma ve amirin yetkisini kötüye kullanması) bu farklılık istatistiki olarak anlamlı düzeydedir.

Tablo 6: Meslek Etiği Algı Düzeylerinin Demografik Değişkenlere Göre Farklılaşma Analizi

\begin{tabular}{|c|c|c|c|c|c|}
\hline Değişken & Bireysel Hak. İhlali & $\begin{array}{c}\text { İş Düzenini } \\
\text { Bozma }\end{array}$ & Yet. Kötü Kul. & $\begin{array}{l}\text { Amir Yet. Kötü } \\
\text { Kul. }\end{array}$ & $\begin{array}{l}\text { Yetersiz } \\
\text { Hizmet }\end{array}$ \\
\hline \multicolumn{6}{|l|}{ Yaş } \\
\hline $20-30$ & 7,0 & 7,3 & 7,4 & 7,5 & 7,8 \\
\hline $31-40$ & 7,0 & 7,2 & 7,5 & 7,1 & 7,7 \\
\hline $41-60$ & 6,8 & 6,8 & 7,3 & 7,6 & 7,7 \\
\hline$F$ & 0,2 & 1,5 & 0,3 & 1,2 & 0,2 \\
\hline \multicolumn{6}{|l|}{ Cinsiyet } \\
\hline Erkek & 6,9 & 7,2 & 7,4 & 7,3 & 7,7 \\
\hline Kadın & 7,8 & 8,5 & 8,0 & 8,2 & 8,7 \\
\hline$t$ & $-1,9 *$ & $-3,0 * *$ & $-1,4$ & $-1,6$ & $-1,9 *$ \\
\hline \multicolumn{6}{|l|}{ Medeni Hal } \\
\hline Bekâr & 7,0 & 7,5 & 7,5 & 7,6 & 7,8 \\
\hline Evli & 6,9 & 7,1 & 7,4 & 7,2 & 7,7 \\
\hline$t$ & 0,6 & $2,0^{*}$ & 0,4 & $1,9^{*}$ & 0,3 \\
\hline \multicolumn{6}{|l|}{ Kıdem } \\
\hline 1-5 Yll & 7,0 & 7,4 & 7,5 & 7,4 & 7,8 \\
\hline 6-10 Yıl & 7,0 & 7,2 & 7,5 & 7,5 & 8,0 \\
\hline 11 Yıl ve Üzeri & 6,8 & 6,9 & 7,2 & 6,9 & 7,5 \\
\hline$F$ & 0,2 & 2,3 & 0,7 & 2,0 & 1,1 \\
\hline
\end{tabular}

*. Değişkenler arasındaki ilişki 0,05 seviyesinde anlamlıdır.

**. Değişkenler arasındaki ilişki 0,01 seviyesinde anlamlıdır. 
Son olarak, Tablo 7'de iş doyum düzeyi ile etik tutum arasındaki korelasyon analizleri sunulmuştur. Korelasyon analizleri, iş doyumunun 20 boyutunun ortalaması ile etik dışı davranışların ciddiyet düzeyi algısının 45 senaryoda örneklenen genel ortalaması ve beş farklı türdeki etik davranışların ortalamaları kullanılarak yapılmıştır. Bu analizlerle katılımcıların iş doyum düzeyleri ile meslek etiği tutumları arasında bir ilişkinin olup olmadığı araştırılmıştır. Tablodaki bulgulara göre katılımcıların ortalama iş doyumu ile ortalama etik algısı arasında anlamlı bir ilişki bulunamamıştır ( $r=$ $0,09, p>0,05)$. Ancak alt boyuttaki beş ana türdeki etik dışı davranışlara ayrı ayrı bakıldığında beş ana türdeki etik davranışların üçü ile iş doyum düzeyi arasında pozitif yönlü anlamlı ilişkiler tespit edilmiştir. Bulgulara göre katılımcılar, iş doyum düzeyi arttıkça bireysel hakların ihlali $(r=0,13, p<0,05)$, polisin yetkisini kötüye kullanması $(r=0,13, p<0,05)$ ve polisin yeterli polislik hizmeti sağlayamaması $(r=0,14$, $p<0,05)$ türündeki etik dışı davranışları daha ciddi ve önemli görmektedirler. Diğer yandan katılımcıların iş doyum düzeylerinin artması veya azalması durumunda iş düzenini bozma ve amirin yetkisini kötüye kullanması türündeki etik dışı davranışlar açısından onların ciddiyet düzeyi algısı anlamlı şekilde farklılaşmamaktadır. Bu bulgulara dayanarak, en azından bazı türdeki etik dışı davranışlara karşı geliştirilen etik tutumlar ile iş doyum düzeyleri arasında bir ilişki olduğu söylenebilir.

Tablo 7: iş Doyumu Düzeyi ile Etik Algısı Arasındaki Korelasyon ( $r$ ) Analizi

\begin{tabular}{ccccccc}
\hline Değişken & $\begin{array}{c}\text { Ortalama Etik } \\
\text { Algısı }\end{array}$ & $\begin{array}{c}\text { Bireysel Hak. } \\
\text { İhlali }\end{array}$ & $\begin{array}{c}\text { İ̧̧ Düzenini } \\
\text { Bozma }\end{array}$ & $\begin{array}{c}\text { Yet. Kötü } \\
\text { Kul. }\end{array}$ & $\begin{array}{c}\text { Amir Yet. } \\
\text { Kötü Kul. }\end{array}$ & $\begin{array}{c}\text { Yetersiz } \\
\text { Hizmet }\end{array}$ \\
\hline $\begin{array}{c}\text { Ortalama Iş̧ } \\
\text { Doyumu }\end{array}$ & 0,09 & $0,13^{*}$ & 0,07 & $0,13^{*}$ & $-0,06$ & $0,14^{*}$
\end{tabular}

*. Değişkenler arasındaki ilişki 0,05 seviyesinde anlamlıdır.

\section{TARTIŞMA ve SONUÇ}

İş doyumu ve meslek etiği olguları, örgütlerin başarılarıyla yakından ilişkili iki önemli kavramdır. Tüm örgütler çalışanlarının iş doyum düzeyinin yüksek olmasını ve iş etiği kurallarına en yüksek düzeyde uyuyor olmalarını ister. Türk Polis Teşkilatında yürütülen hizmetler halkın güvenliği, özgürlüğü ve hayat standardıyla yakından ilişkili olduğundan bu örgütte çalışanların iş doyum düzeyi ve onların meslek etiği kurallarına karşı geliştirdikleri tutumlar kritik bir öneme sahiptir. Bu araştırmada polislerin iş doyum düzeyi ve iş etiği tutumları incelenmiştir. İş doyum düzeyinin örgütler için pek çok olumsuz yansımalarından birisinin de çalışanların meslek etiği ilkelerine karşı olumsuz bir tutum geliştirmesi olabileceği varsayılarak bu iki olgu arasındaki ilişkiler araştırılmıştır.

Araştırmanın bulguları polislerin iş doyumunun 5 üzerinden 3,2 veya 100 üzerinden 64 olduğunu göstermiştir. Bu değer iş doyumu ile alakalı olarak "kararsızım" ile "memnunum" düzeyleri arasında bir değer olup "kararsızım" düzeyine daha yakındır. Daha önceki araştırmalar da polislerin iş doyumlarını benzer düzeyde ölçmüşlerdir (Çelik ve Duran, 2011; Delice, 2014a; Okyay, 2009). Bulgulara göre polislerin cinsiyeti ve medeni durumları onların iş doyum düzeyini farklılaştırmamaktadır. Ancak, yaşı ilerlemiş polisler gençlere göre işlerinden daha fazla memnuniyet duymaktadırlar. Hayat tecrübesi artmış, beklentileri oturaklaşmış ve hayatta bazı kazanımlar elde etmiş yaşı ilerlemiş polislerin işlerinden de daha fazla memnun olmaları doğal karşılanabilir. Kıdem olarak ise orta düzeyde kıdeme sahip olanlar yeni ve eski polislere göre işlerinden daha az memnundurlar. Bu bulguları ise mesleğe yeni girmiş idealist polislerin henüz meslekle ilgili algılarının tam olarak gelişmemesiyle ve emekliliğe yaklaşarak yeni bir hayata hazırlanan yaşlı polislerin de işleriyle ilgili beklentilerinin azalmış olmasıyla açıklamak mümkündür. Demografik değişkenlerin etkisiyle ilgili bu bulgular Delice (2014a) ile uyuşmaktadır. Ancak literatürde demografik değişkenlerin polislerin iş doyumuna etkisi ile birbirinden 
farklı bulgular elde edilmiştir (Baştemur, 2006; Okyay, 2009; Şanlı ve Akbaş, 2009; Şeker ve Zırhlıoğlu, 2009; Yiğit vd., 2011).

Bulgulara göre polislerin işleriyle ilgili en yüksek düzeyde memnun oldukları boyutlar işlerinin başkalarına hizmet etme imkanı vermesi, işlerinin kendilerine bir saygınlık sağlaması, sahip oldukları yetkiler, iş arkadaşları ve yapılan işlerden elde edilen başarma duygusudur. Polislerin iş doyumunun bu alanı nadiren incelenmiştir ve bu nadir araştırmalar bu alanda da farklı bulgular ortaya koymuşlardır (Çelik ve Duran, 2011; Delice, 2014a). Ancak, bu araştırmaların ortak tespiti, iş arkadaşları faktörünün polislerin iş doyumu açısından önemli bir faktör olduğudur. En azı altı ay olmak üzere daha öğrenciyken beraber aynı ortamların paylaşıldığı ve çalışırken hayatların bile birbirlerine emanet edildiği böyle bir meslekte iş arkadaşı faktörünün öne çıkması doğaldır. Polislerin iş doyumunu artırmak için iş yerinde sosyal ortamların ve ilişkilerin artırıması sağlanarak iş arkadaşlığının geliştirilmesi yararlı olacaktır.

Polislerin iş doyum düzeyinin en düşük olduğu boyutlar ise çalışma şartları, terfi olanakları, iş yükü miktarı, amirlerin karar verme yeteneği ve amirlerin idare tarzıdır. Daha önceki araştırmalar bu etkenleri polisler için birer stres kaynağı ve önemli birer örgütsel sorun olarak nitelemişlerdir (Aydın, 2003; Çam ve Çakır, 2008; Gül ve Delice; Gündüz, Erkan ve Gökçakan, 2007; Sever ve Cinoğlu, 2010; Yılmaz, 2011). Polislerin iş doyumunu artırmak için bu sorunların çözülmesi yararlı olacaktır.

Meslek etiği tutumuyla ilgili bulgulara gelince, bulgular polislerin bir kısım etik dışı davranışları bazı diğerlerine göre daha ciddi ve önemli olarak algıladıklarını göstermiştir. Polislerin en ciddi ve en önemli gördükleri etik dışı davranışlar; her türüyle rüşvet alınması, olay yerindeki kıymetli eşyanın cebe atılması, suç kayıtlarının değiştirilmesi, görevliyken erkek polisin bayan astının rızasız yüzünü okşaması, görevdeyken içki içilmesi, şüphelinin üzerine sonradan silah yerleştirilmesi, bir olayla ilgili yanlış bir olay yeri tutanağı hazırlanması ve polis yöneticisinin makam arabasını ve şoförünü özel işlerinde kullanması gibi davranışlardır. Polislerin diğerlerine göre daha az ve önemli gördükleri davranışlar ise; trafik cezasından kurtulabilmek için polis kimliğinin gösterilmesi, acil bir durum olmamasına rağmen hız sınırı üzerinde araç kullanması, göreve yeni başlayan polis amirinin esnafın çiçek ve çikolata hediyelerini kabul etmesi, uğraşılarak yakalanan hırsılık şüphelisine bir iki yumruk atılması, suçları önlemek için sokakta insanların üzerinin rastgele aranması, gizli çalışan narkotik polisinin uyuşturucu çetesinin güvenini kazanmak için kokain kullanması, hırsızlık sabıkalısının sokakta nedensiz üzerinin aranması, komşunun karıştığı darp olayı hakkında işlem yapılmaması, uyuşturucudan sabıkası olan vatandaşın izinsiz arabasının aranması ve polis yöneticisinin emniyet hizmetlerinde kullanılmak üzere esnafın yardımlarını kabul etmesi gibi davranışlardır. Bu bulgular daha önce yapılmış yerli ve yabancı araştırmaların bulgularıyla paraleldir (Bal ve Beren, 2003; Boles, 1995; Cerrah vd., 2009; Chiristine, 1994; Delice, 2014b; Delice, 2014c; IACP, 2012). Bulgular, polislerin ciddi ve önemli gördükleri davranışların en yüksek düzeyde cezalandırılmaları gerektiğini düşündüklerini de göstermiştir ki bu bulgular da daha önce yapılmış araştırmalarla uyumludur. Yine bulgular polislerin bazı etik dışı davranışların diğer bazılarına göre daha sık yaşandığını düşündüklerini göstermiştir. Bulgulara göre etik dışı davranışların yaşanma sıklığı ile davranışların ciddiyet düzeyi arasında zayıf da olsa negatif yönlü ve anlamlı bir ilişki bulunmaktadır ki bu da polislerin daha ciddi ve önemli gördükleri etik dışı davranışların polis teşkilatında daha az sıklıkla yaşandığını düşündüklerini göstermektedir. Bu bulgu da daha önce bu konuda yapılmış araştırmaları desteklemiştir (Chiristine, 1994; Delice, 2014b; Delice, 2014c).

Etik dışı davranışların gruplandığı beş ana türdeki davranışlar açısından ise bulgular, polislerin en ciddi ve önemli gördükleri etik dışı davranış türünün yeterli polislik hizmeti sağlanamaması olduğunu, an az ciddi gördükleri etik dışı davranış türünün ise bireysel hakların ihlali türündeki davranışlar olduğunu göstermiştir. Olması gereken, polisin verdiği diğer hizmetlerin de gayesi olan bireysel hakların kullanılmasının en yüksek düzeyde sağlanmasının polisler tarafından daha çok önemsenmesidir. Bu nedenle bu konudaki tutumun daha olumlu hale getirilebilmesi için polislere verilen etik eğitimlerinde bireysel haklara daha çok önem verilmelidir. 
Bu beş ana türdeki etik dışı davranışlara verilmesi gereken ceza düzeyi açısından baktığımızda polislerin en ciddi gördükleri etik dışı davranış türü olan yeterli polislik hizmeti sağlanamaması türündeki davranışlara en düşük düzeyde ceza öngördükleri anlaşılmaktadır. Bu beş ana etik dışı davranış türünün polisler tarafından algılanan yaşanma sıklığına baktığımızda ise en az yaşandığı düşünülen davranış türü yine yeterli polislik hizmeti sağlanamaması türündeki davranışlar olarak karşımıza çıkmaktadır. Bu farklı yönleriyle bu davranış türü ilerdeki araştırmaların konusu olmalıdır. En sık yaşandığı düşünülen davranış türü ise polis amirinin yetkisini kötüye kullanması türündeki davranışlardır ki bu tür davranışların yaşanma sıklığı ortalaması diğerlerinden belirgin şekilde yüksektir. Bu bulgu dikkat çekicidir. Bununla beraber bu bulgu değerlendirilirken katılımcıların tamamının polis memuru olduğu ve polislik mesleğindeki katı hiyerarşik yapıdan dolayı polis amirlerinin pek sevilmediği dikkate alınmalıdır.

Polislerin meslek etiği tutumlarının demografik özelliklere göre nasıl farklılaştığına gelince, bulgular polislerin yaşları ve kıdemleri değişse bile onların etik tutumlarının farklılaşmadığını göstermiştir. Ancak kadın polislerin ve bekâr polislerin etik dışı davranışları erkek ve evli olanlara göre daha çok önemsedikleri bulunmuş ve bu farklılığın beş ana türdeki etik dışı davranışların bazılarında anlamlı olduğu görülmüştür. Bir diğer deyişle, cinsiyet ve medeni hal değişkenlerine göre polislerin etik tutumları kısmı bir farklılaşma göstermektedir. Daha önce yapılmış bir araştırmada ise bunun tam tersi tespit edilmiş; etik tutumların yaşa ve kıdeme göre farklılaştığı ancak cinsiyet ve medeni hal değişkenleri açısından farklılaşmadığı bulunmuştur (Delice, 2014b).

Son olarak bulgular, polislerin iş doyum düzeyleri ile meslek etiği tutumları arasında nispi de olsa anlamlı bir ilişki olduğunu göstermiştir. İ̧̧ doyum düzeyleri arttıkça bireysel hakların ihlali, polisin yetkisini kötüye kullanması ve polisin yeterli polislik hizmeti sağlayamaması türündeki etik dışı davranışları polisler daha ciddi ve önemli olarak algılamaktadırlar. Bu ilişki zayıf da olsa istatistiki olarak anlamlıdır. İ̧ doyum düzeyinin düşük olmasının çalışanlar üzerinde pek çok olumsuz etki bıraktığı ve bunların örgüte farklı zararlar verdiği pek çok bilimsel araştırma ile gösterilmiştir. Bu araştırmada elde edilen bulgular düşük düzeyli iş doyumunun olumsuz bir yansımasının da çalışanların meslek etiği tutumlarının olumsuz etkilenmesi olabileceğini göstermiştir. Ancak, bu ilişki daha önce hiç araştırımadığı için bu bulguya intiyatla yaklaşımalıdır ve ilerdeki araştırmalar mutlaka bu ilişkiyi yeniden incelemelidir.

Sonuç olarak, bu araştırmanın bulguları polislerin bazı etik dışı davranışları diğerlerine göre daha ciddi ve önemli gördüklerini, daha ciddi görülen etik dışı davranışlara daha yüksek düzeyde ceza öngördüklerini, ancak daha ciddi görülen etik dışı davranışların polis teşkilatında daha nadir yaşandığını düşündüklerini göstermiştir. Daha önemlisi bu araştırmada polislerin etik dışı davranışları ciddi ve önemli görme düzeylerinin onların iş doyum düzeyiyle kısmen de olsa ilişkili olduğu bulunmuştur. Bu bulguların polislerin iş doyumunun ve polis meslek etiği ilkelerin önemini göstermesi açısından kıymetli olduğu değerlendirilmektedir. Polislerin iş doyum ve meslek etiği tutumlarını anlamak ve bu iki olgu açııından polis teşkilatında doğru adımları atabilmek bu bulguların yararlı olabileceği düşünülmektedir.

\section{REFERENCES}

- AHLF, E. H. (2007). Polis Yönetiminde Etik (Çev. Mehmet Öztürk). Ankara: EGM Basımevi.

- AKDOĞAN, H. ve KÖSE, Y. (2012). Polislerin İş Tatmininde Terfi Sistemleri ve Rütbenin Rolü Üzerine Bir Meta Analiz. Polis Bilimleri Dergisi, 14(2), 51-74.

- AKINCI, Z. (2002). Turizm Sektöründe İşgörenin İş Tatminini Etkileyen Faktörler: 5 Yıldızlı Konaklama İşletmelerinde Bir Uygulama. Akdeniz Üniversitesi, I.I.B.F. Dergisi, 4, 1-26. 
- ARVEY, R. D., CARTER G. D. and BUERKLEY D.K. (1991). Job Satisfaction: Dispositional and Situational Influences. In C.L. Cooper \& I.T. Robertson (Eds.), International Review of Industrial and Organizational Psychology, NY: John Wiley, Vol.6, s. 359-383.

- ATMACA, K. (2010). İnsan Kaynakları Yönetimi ve Etik. Sayıştay Dergisi, 76, 63-76.

- AYDIN, A. H. (2003). Polisin Güncel Sorunları: Bir neden-sonuç analizi. Polis Bilimleri Dergisi, 5(3-4), 1-12.

- BAL, İ. ve Beren, F. (2003). Polis Etiği. Ankara: Siyasal Kitapevi.

- BARUTÇUGİL, İ. (2004). Stratejik İnsan Kaynakları Yönetim. İstanbul: Kariyer Yayıncılik.

- BAŞTEMUR, Y. (2006). İş Tatmini İle Yaşam Tatmini Arasındaki İlişkiler: Kayseri Emniyet Müdürlügünde Bir Araştırma. Yayınlanmamış Yüksek Lisans Tezi, Erciyes Üniversitesi Sosyal Bilimler Enstitüsü.

- $\quad$ BEDÜK, A., ERDEMİ, N. K. ve ÖZ, M. (2005).Polis Meslek Etiği: Karaman İlinde Bir Araştırma. 2. Yönetimde ve Siyasette Etik Sempozyumu, Sakarya.

- BEREN, F. (2001). Türkiye'deki Polislik Uygulamaları Perspektifinden Polis Meslek Etiği. Polis Bilimleri Dergisi, 3(1), 75-98.

- BLAU, P. (1964). Exchange and Power in Social Life. New York: Wiley.

- BOLES, M. L. (1995). Institutionalizing Ethics for theNext Century. http://www.fdle.state.fl.us/Content/getdoc/a1115487-9c07-45bc-9b24192515fc628a/Boles-michael-paper.aspx, (Erişim Tarihi: 08.07.2013).

- $\quad$ BOZKURT, Ö. ve BOZKURT İ.. (2008). İş Tatminini Etkileyen İşletme İçi Faktörlerin Eğitim Sektörü Açısından Değerlendirilmesine Yönelik Bir Alan Araştırması. Doğuş Üniversitesi Dergisi, 9(1), 1-18.

- BURNEY, L. L. and SWANSON, N. J. (2010). The Relationship Between Balanced Scorecard Characteristics and Managers' Job Satisfaction. Journal Of Managerial Issues, XXII(2), 166-181.

- CERRAH, İ., Çevik, H. H., Göksu, T. And Balcioğlu, E. (2009). Ethics for the Prevention of Corruption in Turkey. Academic Research Report Ethical Conduct in Law Enforcement.

- CERRAH, İbrahim (2012). Polis Etiği. Ankara: Polis Akademisi Yayınları.

- Chen, L. H. (2008). Job Satisfaction Among Information System (IS) Personel. Computer in Human Behavior, 24(1), 105-118.

- CHİRISTINE, M. (1994). Illinois Municipal Officers' Perceptions of PoliceEthics. Statistical Analysis Center: Illinois Criminal Justice Information Authority.

- CURTIS E. A. (2007). Job satisfaction: a survey of nurses in the Republic of Ireland. International Nursing Review, 54, 92-99.

- ÇAKIR, Ö. (2001). İse Bağlllık Olgusu ve Etkileyen Faktörler. Ankara: Seçkin Yayıncilık.

- ÇAM, S. ve ÇAKIR, İ. (2008). Polislerde İş Stresi Algısının Kişisel ve Göreve Bağlı Bazı Değişkenlere Göre Karşılaştırılması. Polis Bilimleri Dergisi, 10(3), ss.21-40.

- ÇARIKÇI, İ H. (2000). Çalışanların İş Tatminlerini Etkileyen Kişisel Özellikler: Süpermarket Çalışanları Üzerinde Bir Araştırma. Süleyman Demirel Üniversitesi İktisadi İdari Bilimler Fakültesi Dergisi, 5(2), 155-168.

- ÇELIKK, M. ve DURAN H: (2011). Toplam Kalite Yönetimi Ve Örgütsel Bağl1lık: Adıyaman Emniyet Müdürlüğü Örneği. Akademik Bakış Dergisi, 24, 1-22. 
- DAVIS, G. (2004). Job Satisfaction Survey Among Employees in Small Business. Journal of Small Business and Enterprise Development, 11(4), 495-503.

- DAVIS, M. (1991). Do cops really need a code of ethics? Criminal Justice Ethics, 10(2), 14-28.

- DELİCE, M. (2014a). İş Doyumunu Etkileyen Faktörlerin Hiyerarşik Regresyon Yöntemiyle ve Nitel Olarak İncelenmesi. Türk İdare Dergisi, 479, 59-90.

- DELİCE, M. ve GÜL, Z. (2012). Kararlara Katılımın Çalışanlarda Oluşturduğu Algının İncelenmesi: Polis Teşkilatı Örneği. EKEV Akademi Dergisi, 16(52), 15-28.

- DELİCE, M. (2014b). Meslek Etiği Kavramları. Atak, Selçuk ve Gül, Serdar Kenan (Ed.) içinde, Polis Etiği Üzerine Bir Araştırma: PMYO Öğrencilerinin Meslek Etiği Algilarının İncelenmesi, 439-458. Ankara: Adalet Yayınc1lı.

- DELİCE, Murat (2014c), Polislerin Meslek Etiği Algılarının İncelenmesi. Atatürk Üniversitesi Sosyal Bilimler Enstitüsü Dergisi, 18(1), 363-385.

- DELIORMAN R. B. ve Kandemir A. Ü. (2009). Kamu Kurumu Niteliğinde Meslek Kuruluşları ve Etik. Kamu Etiği Akademik Araştırmaları içinde, Cilt 2, Ankara, 10-99.

- DESHON, R. W. (2000). Police Officers Oath Of Office And Code Of Ethics A Question Of Knowledge. Eastern Michigan UniversitySchool of Police Staff and Command Publications.

- DONUK, B. (2009). Özel ve Kamu Sektöründe Görev Yapan Spor Yöneticilerin İş Tatminlerinin Karşılaştırılması. Selçuk Üniversitesi Sosyal Bilimler Enstitüsü Dergisi, $21,179-185$.

- EDVARDSSON, B. and GUSTAVSSON, B. O. (2003). Quality in The Work Environment: A Prerequisite for Success in New Service Development. Managing Service Quality, 13(2), 148-163.

- EĞİNLİ, A. T. (2009). Çalışanlarda İş Doyumu: Kamu Ve Özel Sektör Çalışanlarının İş Doyumuna Yönelik Bir Araştırma. Atatürk Üniversitesi İktisadi ve İdari Bilimler Dergisi, 23(3), 35-52.

- Emniyet Genel Müdürlüğü (2013). 2012 Yllı Faaliyet Raporu. Ankara: Başak Matbaacilik.

- ERDEM, A. R. ve DEMIREL, F. (2009). Sinıf Öğretmenlerinin "Denetim" Boyutuna İlişkin İş Doyum Düzeyi. e-Journal of New World Sciences Academy, 4(1), 44-61.

- FRENCH, L. A. (2008). Accessing And Training Police And Security Personnel Relevant To Ethnic And Cultural Sensitivity. The Researcher, Vol. XXI(4), 51-71.

- GİRGIN, G. (2009). Öğretmenlerin İş Doyumuna Etki Eden Faktörlerin İncelenmesi. E-Journal Of New World Sciences Academy, 4(4), 1297-1307.

- GREENE, J. R., PIQQUERO, A. R., HİCKMAN, M. J. and LAWTON, B. A. (2004). Police Integrity and Accountability in Philadelphia: Predicting and AssessingPolice Misconduct. U.S.: Department of Justice Publications.

- GÜL, Z. ve DELİCE, M. (2011). Polis Meslek Stresi ve Stres Azaltma/Stresle Başa çıkma Programları: Eşlerle ilişkileri üzerine etkileri. Polis Bilimleri Dergisi, 13(3), 1938 .

- GÜNDÜZ, B., ERKAN, Z. ve GÖKÇAKAN, N. (2007). Polislerde Tükenmişlik ve Görülen Psikolojik Belirtiler. Ç.Ü. Sosyal Bilimler Enstitüsü Dergisi, Cilt 16, Sayı 2, 2007, s.283-298

- International Association Of Chief Of Police (2012). Ethics Training in Law Enforcement: A reportbytheEthics Training Subcommittee of the IACP Ad Hoc 

Arasında Bir İlişki Var mı?

Committee on Police Image and Ethics. http://www.theiacp.org/PoliceServices/ProfessionalAssistance/Ethics/ReportsResourc es/EthicsTraininginLawEnforcement/tabid/194/Default.aspx, (Erișim Tarihi: $\underline{08.07 .2013)}$

- $\quad$ İŞCAN, Ö. F. ve TİMUROĞLU M. K. (2007). Örgüt Kültürünün İş Tatmini Üzerindeki Etkisi ve Bir Uygulama. Atatürk Üniversitesi, I.I.I.B.F. Dergisi, 21(1), 119-135.

- KESER, A. (2006). Çalışma Yaşamında Motivasyon. İstanbul: Alfa Aktüel Yayınları.

- KOCABIYIK, Z. O. ve ÇAKICI, E. (2008). Sağlık Çalışanlarında Tükenmişlik Ve İş Doyumu. Anadolu Psikiyatri Dergisi, 9, 132-138.

- KÖROĞLU, Ö. (2011). İş Doyumu Ve Motivasyon Düzeylerini Etkileyen Faktörlerin Performansla Ilişkisi: Turist Rehberleri Üzerine Bir Araştırma. Yayınlanmamış Doktora Tezi, Balıkesir Üniversitesi Sosyal Bilimler Enstitüsü Turizm İşletmeciliği ve Otelcilik Anabilim Dalı.

- LUTHANS, F. (1992). Organizational Behavior, 6th Edition. New York: McGraw-Hill.

- MAlHOTRA, N. and MUKHERJEE. A. (2004). The relative influence of organisational commitment and job satisfaction on service quality of customer-contact employees in banking call centres. Journal of Services Marketing, 18(3), 162-174.

- MASIAPATA, N. M. (2007). Ethics and ethos in the South Africanpolice service: an overview of the Johannesburg central police station. Yayınlanmamış Yüksek Lisans Tezi, Pretoria Üniversitesi.

- Milli Eğitim Bakanlığı (2006). Meslekî Eğitim Ve Öğretim Sisteminin Güçlendirilmesi Projesi, Tümalanlar: Meslek Etiği.

- OKPARA, J. O. (2006). The Relationship Of Personal Characteristics And Job Satisfaction: A Study Of Nigerian Managers in The Oil Industry. The Journal of American Academy Of Business, 10(1), 49-58.

- OKYAY, N. (2009). Emniyet Teşkilatına Bağll Okullardan Mezun Olup Çevik Kuvvet Şube Müdürlügüunde Görev Yapan Polislerin Psikolojik Hizmet Algıları, İs Doyumu Ve Tükenmişlik Düzeyinin Incelenmesi. Yayınlanmamış Yüksek Lisans Tezi, Çukurova Üniversitesi Sosyal Bilimler Enstitüsü Eğitim Bilimleri Anabilim Dalı.

- ÖZDEMIR, F. (2006). Örgütsel İklimin Isş Tatmin Düzeyine Etkisi: Tekstil Sektöründe Bir Araştırma. Yayınlanmamış Doktora Tezi. Çukurova Üniversitesi Sosyal Bilimler Enstitüsü, Adana.

- ÖZGEN, H., ÖZTÜRK, A. ve YALÇIN A. (2002). Insan Kaynakları Yönetimi. Adana: Nobel Yayincilik.

- ROWE, M. (2007). Tripping Over Molehills: Ethics and the Ethnography of PoliceWork. International Journal of Social Research Methodology, 10(1), 37-48

- SEVER, M. ve CINOĞLU, H. (2010). Amerikan Polisinde İş Stresinden Kaynaklanan Aile İçi Şiddet Olaylarının Sosyolojik Ve İstatistiksel Analizi. Polis Bilimleri Dergisi, 12(1), 125-146.

- SEVIMLİ, F. ve ÖMER F. İ. (2005). Bireysel ve İş Ortamına Ait Etkenler Açısından İş Doyumu. Ege Üniversitesi, İ.̇.B.F. Akademik Bakış Dergisi, 5(1-2), 55-64.

- SIĞRI, Ü. ve BASIM, N. (2006). İş Görenlerin İş Doyumu İle Örgütsel Bağlılık Düzeylerinin Analizi: Kamu ve Özel Sektörde Karşılaştırmalı Bir Araştırma. Selçuk Üniversitesi İktisadi ve İdari Bilimler Fakültesi Sosyal ve Ekonomik Araştırmalar Dergisi, 6(12), 131-154.

- SOLMUŞ, T., (2004). İş Yaşamında Duygular ve Kişilerarası İlişkiler; Psikoloji Penceresinden Insan Kaynakları Yönetimi. İstanbul: Beta Yayınları. 
- SÖZEN, S. (2004). Polis ve Profesyonellik. Polis Bilimleri Dergisi, 6(3-4), 115-130.

- SPECTOR, P.E. (1997). Job Satisfaction: Application, assessment, cause, and consequences. California: SAGE Publications.

- SUN, H. Ö. (2002). İş Doyumu Üzerine Bir Araştırma: Türkiye Cumhuriyet Merkez Bankası Banknot Matbaası Genel Müdürlüğü. Ankara: Türkiye Cumhuriyet Merkez Bankası Banknot Matbaası Genel Müdürlüğ̈̈.

- ŞANLI, S. ve AKBAŞ, T. (2009). Adana ilinde Çalışan Polislerin İş Doyumu Düzeylerinin Bazı Değişkenler Açısından İncelenmesi. Polis Bilimler Dergisi, 11(2), 73-86.

- ŞEKER, B. D. ve ZIRHLIOĞLU, G. (2009). Van Emniyet Müdürlüğü Kadrosunda Çalışan Polislerin Tükenmişlik, İş Doyumu ve Yaşam Doyumları Arasındaki İlişkilerin Değerlendirilmesi. Polis Bilimleri Dergisi, 11(4), 1-26.

- TENGILİMOĞLU, D. ve YİĞİT, A., (2005). Hastanelerde Liderlik Davranışlarının Personel İş Doyumuna Etkisini Belirlemeye Yönelik Bir Alan Çalışması. Hacettepe Sağllk İdaresi Dergisi, 8 (3), 375-401.

- The Institute for Law Enforcement Administration (2012). Reception of Ethics Training by Participants. US: The Center for Law Enforcement Ethics.

- WYATT-NICHOL, H. and FRANKS, G. (2009). Ethics Training in Law Enforcement Agencies. PublicIntegrity, 12(1), 39-50.

- YAPRAKLI, Ş. ve YILMAZ, M. Y. (2007). Çalışanların İş Stresi Algılarının İş Tatminleri Üzerindeki Etkisi: Erzurum'da İlaç Mümessilleri Üzerinde Bir Saha Araştırması. Atatürk Üniversitesi İktisadi İdari Bilimler Dergisi, 21(1), 154-183.

- YILMAZ, H. (2011). Mesai Düzenlemesinin Örgütsel Performans, Personel Tatmini Ve Suç Önleme Üzerine Etkileri: Bursa Emniyet Müdürlüğ̈̈ Ergonomik Vardiya Uygulaması. Yüksek Lisans Bitirme Projesi, Atatürk Üniversitesi Sosyal Bilimler Enstitüsü Güvenlik Ve Adli Bilimler Ana Bilim Dalı.

- YİĞIT, R., DİLMAÇ, B. ve DENIZ, M. E. (2011). İş Ve Yaşam Doyumu: Konya Emniyet Müdürlüğü Alan Araştırması. Polis Bilimleri Dergisi, 13(3), 1-18.

- YÜKSEL, İ. (2003). Hemşirelerin İş Güçlüğünü Oluşturan Değişkenlerin İş Doyumu, İş Gerilimi Ve Örgütsel Bağlılık Üzerindeki Etkisinin Analizi. Fırat Üniversitesi Sosyal Bilimler Dergisi, 13(1), 261-272. 